\title{
An examination of urban heat island characteristics in a global climate model
}

\author{
K. W. Oleson, ${ }^{\mathrm{a} *}$ G. B. Bonan, ${ }^{\mathrm{a}}$ J. Feddema ${ }^{\mathrm{b}}$ and T. Jackson ${ }^{\mathrm{b}}$ \\ ${ }^{a}$ Climate and Global Dynamics Division, National Center for Atmospheric Research, Boulder, CO 80307-3000, USA \\ ${ }^{\mathrm{b}}$ Department of Geography, University of Kansas, Lawrence, KS, USA
}

\begin{abstract}
A parameterization for urban surfaces has been incorporated into the Community Land Model as part of the Community Climate System Model. The parameterization allows global simulation of the urban environment, in particular the temperature of cities and thus the urban heat island. Here, the results from climate simulations for the AR4 A2 emissions scenario are presented. Present-day annual mean urban air temperatures are up to $4{ }^{\circ} \mathrm{C}$ warmer than surrounding rural areas. Averaged over all urban areas resolved in the model, the heat island is $1.1{ }^{\circ} \mathrm{C}$, which is $46 \%$ of the simulated mid-century warming over global land due to greenhouse gases. Heat islands are generally largest at night as evidenced by a larger urban warming in minimum than maximum temperature, resulting in a smaller diurnal temperature range compared to rural areas. Spatial and seasonal variability in the heat island is caused by urban to rural contrasts in energy balance and the different responses of these surfaces to the seasonal cycle of climate. Under simulation constraints of no urban growth and identical urban/rural atmospheric forcing, the urban to rural contrast decreases slightly by the end of the century. This is primarily a different response of rural and urban areas to increased long-wave radiation from a warmer atmosphere. The larger storage capacity of urban areas buffers the increase in long-wave radiation such that urban night-time temperatures warm less than rural. Space heating and air conditioning processes add about $0.01 \mathrm{~W} \mathrm{~m}^{-2}$ of heat distributed globally, which results in a small increase in the heat island. The significant differences between urban and rural surfaces demonstrated here imply that climate models need to account for urban surfaces to more realistically evaluate the impact of climate change on people in the environment where they live. Copyright (c 2010 Royal Meteorological Society
\end{abstract}

KEY WORDS global climate model; urban model; urban heat island; surface energy balance

Received 14 September 2009; Revised 20 May 2010; Accepted 16 June 2010

\section{Introduction}

Most of the global climate models that are utilized for climate change research do not account for urban surfaces (Best, 2006). This is likely because urban areas represent a small fraction of the global land surface $(1-4 \%)$ and thus their influence on large-scale temporal and spatial averages is small (Trenberth et al., 2007). However, a large proportion of the world's population resides in these areas $(>50 \%)$ and experiences urban climates. There are significant differences in energy balance, temperature, humidity and run-off between urban areas and the vegetated or 'rural' surfaces typically represented in climate models (Oke, 1987). Therefore, it is appropriate to begin to address the lack of representation of this land surface type in global climate models so that these models can better assess climate impacts on urban populations.

The differences between urban and rural surfaces manifest themselves in the urban heat island effect (Landsberg, 1981), in which cities are warmer than their

\footnotetext{
* Correspondence to: K. W. Oleson, Climate and Global Dynamics Division, National Center for Atmospheric Research, PO Box 3000 Boulder, CO 80307-3000, USA. E-mail: oleson@ucar.edu
}

surrounding rural environs. Urban warming in addition to greenhouse gas-induced warming has not explicitly been taken into account in climate change simulations to date (IPCC, 2007). This additional warming may mean that, for example, future projections of heatrelated mortality which rely on temperature thresholds applied to climate model data (Gosling et al., 2009a) could be underestimated (Changnon et al., 1996). In addition, changes in variability of temperature (e.g. extremes), which may have different behaviour in urban areas can be as important as mean temperature in assessing future heat-related mortality (Gosling et al., 2009b). These issues have added importance when one considers that in some regions heat waves are expected to increase in intensity, frequency and duration in the future (Meehl and Tebaldi, 2004; Clark et al., 2006; Meehl et al., 2007). Changes in mean and variability of temperature as experienced in urban areas can also have implications for energy consumption (Hadley et al., 2006).

An approach to assess the impact of greenhouse gasinduced climate change on cities is to assume stationarity of the urban climate and overlay a present-day urban heat island pattern on a climate change simulation (Betts 
and Best, 2004). However, Betts and Best (2004) have shown that the assumption of stationarity may not be valid for the heat island under modified forcings. Hence, Best (2006) argues for explicit representation of urban areas in climate models.

As a first step in representing differences between urban and rural areas in a climate model, a parameterization for urban surfaces has been incorporated into the community land model (CLM) as part of the community climate system model (CCSM) (Collins et al., 2006a) project at the National Center for Atmospheric Research (NCAR). The purpose of the urban model (CLMU) when coupled with CCSM is to provide climate and climate change information (e.g. near-surface air temperature and humidity, surface hydrology, energy balance, etc.) for urban environments. The urban model has previously been described in detail by Oleson et al. (2008a) and its performance has been evaluated against measured fluxes and temperatures from urban flux tower sites. Results indicate the model is reasonably successful at simulating the energy balance of cities. In offline simulations (i.e. uncoupled to an atmospheric model), the model reproduces some known features of urban climatology in a qualitative sense, including urban heat islands (Oleson et al., 2008b).

The purpose of this paper is to examine the behaviour of the urban model in the context of global climate simulations. The near-surface urban and rural climates produced by the model when coupled to an atmospheric model are contrasted under present day and future climatic conditions for the 21 st century. To our knowledge, these are the first coupled climate model simulations that incorporate an urban canyon model. The focus of the analysis here is mainly on the spatial and temporal aspects of the heat island produced by the model and on the influence of space heating, air conditioning and waste heat on the heat island.

\section{Description of models}

The urban model is coupled to CLM and the community atmosphere model (CAM), which are the land and atmospheric components of CCSM, respectively. The atmospheric model is a successor to version 3.0 of CAM (Collins et al., 2006b), which incorporates changes to the deep convection parameterization and is described by Neale et al. (2008) (hereafter referred to as CAM3.5). CAM3.5 is configured here with a finite volume dynamical core, 26 vertical levels and $1.9^{\circ}$ latitude $\times 2.5^{\circ}$ longitude grid. Urban areas are parameterized by CLMU and the remainder of the global land surface is modelled by CLM version 3.5 (CLM3.5; Oleson et al., 2008c; Stöckli et al., 2008).

Land surface heterogeneity in CLM is represented as a nested subgrid hierarchy (Figure 1) in which grid cells are composed of multiple landunits, snow/soil columns and plant functional types (PFTs). Each grid cell can have different number of landunits, each landunit can have different number of columns and each column can have multiple PFTs. The first subgrid level, the landunit, captures the broadest spatial patterns of subgrid heterogeneity. The landunits are glacier, lake, wetland, vegetated and urban. For vegetated landunits, the second subgrid level, the column, represents soil and snow state variables. The snow/soil column consists of ten layers for soil and up to five layers for snow, depending on snow depth. The urban landunit has five columns (roof, sunlit and shaded wall, and pervious and impervious canyon floor). Each urban column is divided into ten layers for temperature and hydrology calculations, and an additional five layers for snow where appropriate. The third subgrid level is referred to as the PFT level, but also includes the treatment for bare ground. It is intended to capture the biogeophysical and biogeochemical differences between broad categories of plants in terms of their functional characteristics.

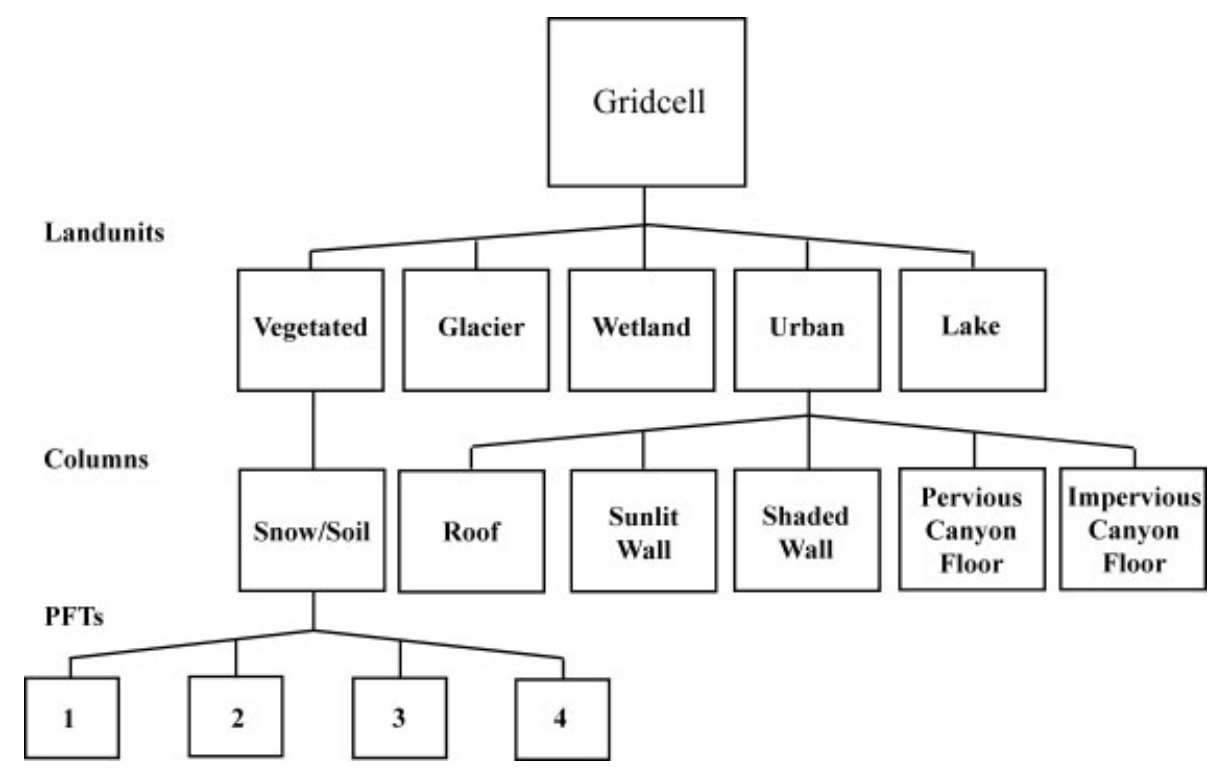

Figure 1. The CLM subgrid hierarchy emphasizing the vegetated and urban landunits. 
The urban columns are arranged in an 'urban canyon' configuration (Oke, 1987) in which the canyon geometry is described by building height $(H)$ and street width $(W)$ (Figure 2). The canyon system consists of roofs, walls and canyon floor. Walls are further divided into shaded and sunlit components. The canyon floor is divided into pervious (e.g. to represent residential lawns, parks) and impervious (e.g. to represent roads, parking lots, sidewalks) fractions. Vegetation is not explicitly modelled for the pervious fraction; instead evaporation is parameterized by a simplified bulk scheme. Evaporation is a function of the wetness of the entire soil column and water is removed from each soil layer according to a wetness factor. Turbulent [sensible heat $\left(Q_{\mathrm{H}, \mathrm{u}}\right)$ and latent heat $\left.\left(Q_{\mathrm{E}, \mathrm{u}}\right)\right]$ and storage $\left(Q_{\mathrm{S}, \mathrm{u}}\right)$ heat fluxes, and surface $\left(T_{\mathrm{u}, \mathrm{s}}\right)$ and internal $\left(T_{\mathrm{u}, 1 \cdots 10}\right)$ temperatures are determined for each urban surface (u). The interior boundary conditions for roofs and walls are determined by an interior building temperature $\left(T_{\mathrm{iB}}\right)$ held between prescribed minimum and maximum temperatures $\left(T_{\mathrm{BB}, \min }\right.$ and $\left.T_{\mathrm{iB}, \max }\right)$, thus explicitly resolving heating and air conditioning (HAC) fluxes. Hydrology on the roof and canyon floor is simulated and the walls are hydrologically inactive. A snowpack can form on the active surfaces. A certain amount of liquid water is allowed to pond on these surfaces, which supports evaporation. Snowmelt water or water in excess of the maximum ponding depth runs off ( $\left.R_{\text {roof }}, R_{\text {imprvrd }}, R_{\text {prrvrd }}\right)$. Anthropogenic sources of waste heat from $\operatorname{HAC}\left(Q_{\mathrm{H} \text {,waste }}\right)$ are incorporated as modifications to the canyon floor energy budget (Appendix). The heat and moisture fluxes from each surface (including the roof) interact with each other through a bulk air mass that represents air in the urban canopy layer (UCL) for which specific humidity and temperature are predicted. The urban model produces sensible heat, latent heat, momentum fluxes, emitted long wave and reflected solar radiation, which are area-averaged with fluxes from nonurban landunits (e.g. vegetation, lakes) to supply grid-cell averaged fluxes to the atmospheric model.

The urban model used here is the same as that presented by Oleson et al. (2008a) with two exceptions. First, the hydrology of the pervious road has been updated from CLM3.0 (Oleson et al., 2004) to CLM3.5 (Oleson et al., 2008c). The non-vegetation-related improvements in CLM3.5 are incorporated into the pervious road hydrology. These include improved parameterizations for surface and subsurface run-off, the addition of an unconfined aquifer model representing recharge and discharge processes between the soil column and groundwater, and the introduction of the concepts of supercooled soil water and fractional impermeable area. These were shown to result in significant improvements in simulation of evapotranspiration and run-off (Oleson et al., 2008c).

Second, a revised treatment of anthropogenic fluxes has been implemented. In Oleson et al. (2008a), the waste heat generated as a byproduct of HAC was modelled as a sensible heat flux into the UCL. However, it was found that if this flux is large enough, the numerical solution may become unstable because the urban canopy air has no heat capacity and the heat capacities of the roofs and walls are relatively small. Instead, this heat flux is added to the net heat flux for the canyon

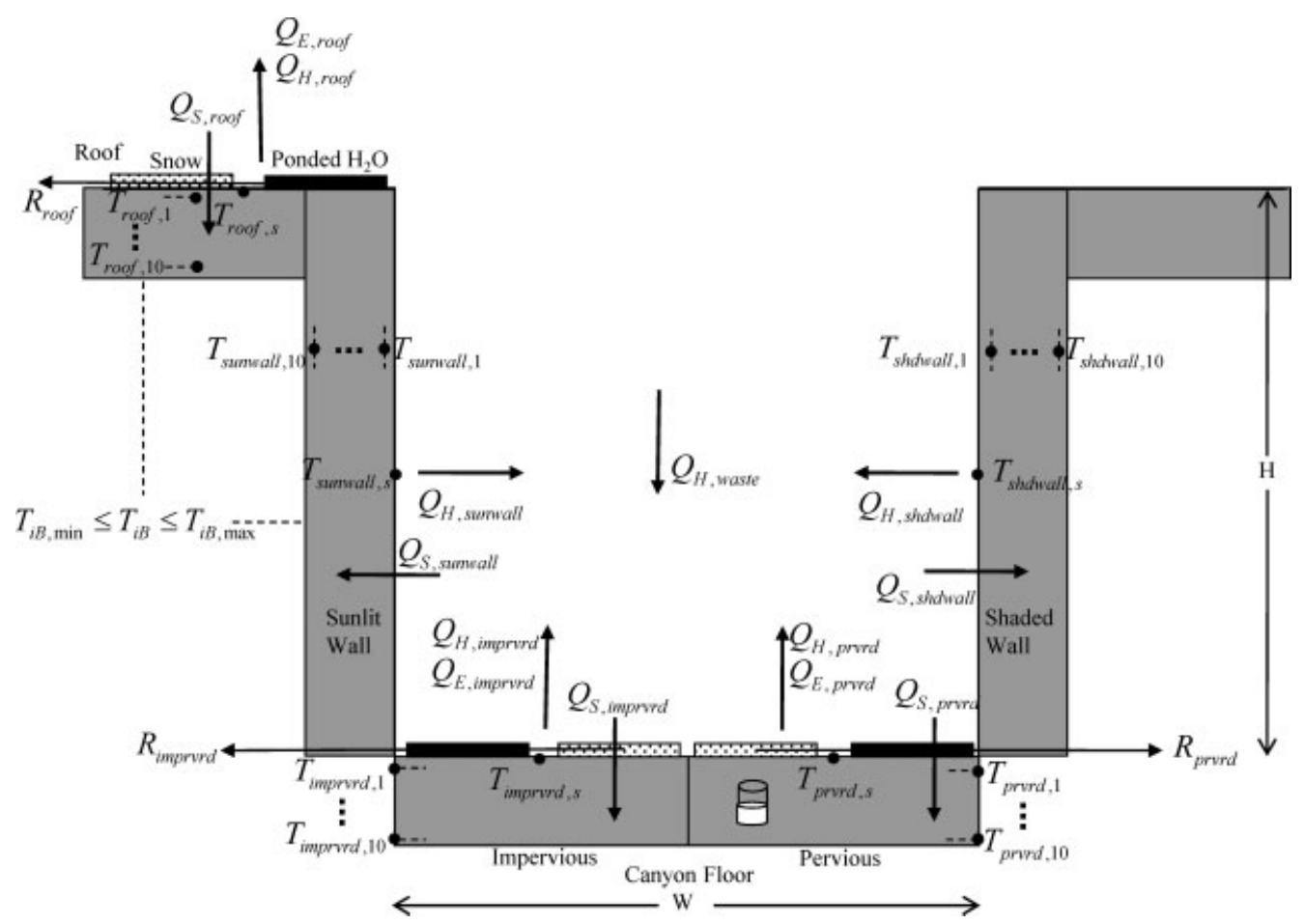

Figure 2. Schematic representation of the urban landunit (modified from Figure 2 of Oleson et al., 2008a). See Section 2 for description of notation. Incident, reflected, and net solar and long-wave radiation are calculated for each individual surface but are not shown for clarity. 
floor (Appendix). A previously neglected term, the heat removed by air conditioning, is added to the net heat flux for the canyon floor as well (Appendix). Although the urban model can incorporate fluxes from other sources such as traffic (Oleson et al., 2008b), the implementation of this awaits a global dataset suitable for providing these fluxes. The performance of this updated version of the urban model for the flux tower sites examined by Oleson et al. (2008a) is nearly identical to the original version because the pervious fraction is nearzero at both sites and anthropogenic fluxes were not included.

\section{Urban surface datasets}

Global applications of the model make use of datasets of present-day urban extent and urban properties developed by Jackson et al. (2010). Urban extent, defined for four classes [tall building district (TBD), and high, medium and low density (HD, MD, LD)], was derived from LandScan 2004 [Oak Ridge National Laboratories (ORNL) 2005, LandScan ${ }^{\text {TM }}$ Global Population Database, Oak Ridge, TN (http://www.ornl.gov/landscan/)], a population density dataset derived from census data, nighttime lights satellite observations, road proximity and slope (Dobson et al., 2000). The urban extent data is aggregated from the original $1 \mathrm{~km}$ resolution to a $0.5^{\circ} \times$ $0.5^{\circ}$ global grid. For this particular implementation, only the sum of the TBD, HD and MD classes are used as the LD class is dominated by vegetation and better modelled as a vegetated/soil surface.

For each of 33 distinct regions across the globe, thermal (e.g. heat capacity and thermal conductivity), radiative (e.g. albedo and emissivity) and morphological (e.g. height to width ratio, roof fraction, average building height and pervious fraction of the canyon floor) properties are provided for each of the density classes (Table I). Building interior minimum and maximum temperatures based on climate and socio-economic considerations are also provided. Urban parameters are determined for the $0.5^{\circ} \times 0.5^{\circ}$ global grid based on the dominant density class by area. This prevents potentially unrealistic parameter values that may result if the density classes are averaged. As a result, the global representation of urban is almost exclusively medium density. The data is then aggregated using area averaging to the desired climate model resolution. It is surmised that the MODIS-based vegetation dataset used in CLM 3.5 classifies built areas as bare soil, thus the urban extent preferentially replaces bare soil when it exists within the grid cell. A very small minimum threshold of $0.1 \%$ of the grid cell by area is used to resolve urban areas. An elevation threshold of $2200 \mathrm{~m}$ is used to eliminate urban areas, where the grid cell surface elevation is significantly higher than the elevation the cities are actually at because of the coarse spatial resolution of the model. This prevents overestimates of anthropogenic heating in winter due to unrealistically cold temperatures.
Table I. Input data required for the urban model.

\begin{tabular}{lll}
\hline Data & Symbol & Units \\
\hline
\end{tabular}

Percent urban

Canyon height to width ratio

Roof fraction

Pervious road fraction ${ }^{\mathrm{a}}$

Emissivity of roof

Emissivity of impervious road

Emissivity of pervious road

Emissivity of sunlit and shaded

walls

Building height

Roof albedo ${ }^{\circ}$

Wall albedo ${ }^{c}$

Impervious road albedo ${ }^{c}$

Pervious road albedo ${ }^{d}$

Roof thermal conductivity

Wall thermal conductivity

Impervious road thermal

conductivity $^{\mathrm{e}}$

Pervious road thermal

conductivity ${ }^{\mathrm{f}}$

Roof volumetric heat capacity

Wall volumetric heat capacity

Impervious road volumetric

heat capacity ${ }^{\mathrm{e}}$

Pervious road volumetric heat capacity $^{\mathrm{f}}$

Maximum interior building

temperature

Minimum interior building

temperature

Height of wind source in

canyon

Number of impervious road

layers

Wall thickness

Roof thickness

Percent sand, percent clay of

pervious road (soil) ${ }^{\mathrm{g}}$

Grid cell latitude and longitude

$\begin{array}{cc}- & \% \\ H / W & - \\ W_{\text {roof }} & - \\ f_{\text {prvrd }} & - \\ \varepsilon_{\text {roof }} & - \\ \varepsilon_{\text {imprrrd }} & - \\ \varepsilon_{\text {prvrd }} & - \\ \varepsilon_{\text {wall }} & -\end{array}$

\begin{tabular}{|c|c|}
\hline$H$ & $\mathrm{~m}$ \\
\hline$\alpha_{\text {roof }}$ & - \\
\hline$\alpha_{\text {wall }}$ & - \\
\hline$\alpha_{\text {imprvrd }}$ & - \\
\hline$\alpha_{\text {prvrd }}$ & - \\
\hline$\lambda_{\text {roof }, i}$ & $\mathrm{~W} \mathrm{~m}^{-1} \mathrm{~K}^{-1}$ \\
\hline$\lambda_{\text {wall }, i}$ & $\mathrm{~W} \mathrm{~m}^{-1} \mathrm{~K}^{-1}$ \\
\hline$\lambda_{\text {imprvrd }, i}$ & $\mathrm{~W} \mathrm{~m}^{-1} \mathrm{~K}^{-1}$ \\
\hline$\lambda_{\text {prvrd }, i}$ & $\mathrm{~W} \mathrm{~m}^{-1} \mathrm{~K}^{-1}$ \\
\hline$c_{\mathrm{roof}, i}$ & $\mathrm{~J} \mathrm{~m}^{-3} \mathrm{~K}^{-1}$ \\
\hline$c_{\text {wall }, i}$ & $\mathrm{~J} \mathrm{~m}^{-3} \mathrm{~K}^{-1}$ \\
\hline$c_{\text {imprvrd, } i}$ & $\mathrm{~J} \mathrm{~m}^{-3} \mathrm{~K}^{-1}$ \\
\hline$c_{\text {prvrd }, i}$ & $\mathrm{~J} \mathrm{~m}^{-3} \mathrm{~K}^{-1}$ \\
\hline$T_{i \mathrm{~B}, \max }$ & K \\
\hline$T_{i \mathrm{~B}, \min }$ & $\mathrm{K}$ \\
\hline$H_{\mathrm{w}}$ & $\mathrm{m}$ \\
\hline
\end{tabular}

a This fraction is relative to the canyon floor.

${ }^{\mathrm{b}}$ Not supplied by urban dataset, set to 0.95 globally.

${ }^{c}$ Albedo from urban dataset assigned to visible and near-infrared, direct and diffuse albedo.

${ }^{\mathrm{d}}$ Not supplied by urban dataset, set to 0.08 globally.

${ }^{\text {e }}$ Required for layers $i=1, N_{\text {imprrrd }}$, derived from soil texturedependent equations for other layers (Oleson et al., 2004).

${ }^{\mathrm{f}}$ Derived from soil texture-dependent equations (Oleson et al., 2004).

g Obtained from grid cell soil texture (Oleson et al., 2004).

\section{Description of urban climate simulations}

Two climate simulations were run from 1941 to 2099 at a spatial resolution of $1.9^{\circ}$ latitude $\times 2.5^{\circ}$ longitude . Sea surface temperatures, sea-ice and greenhouse gases $\left(\mathrm{CO}_{2}, \mathrm{CH}_{4}, \mathrm{~N}_{2} \mathrm{O}, \mathrm{CFCs}\right)$ are prescribed for the period 1941-1999 from an Intergovernmental Panel on Climate Change Fourth Assessment Report (IPCC AR4) 20thcentury CCSM3 ensemble member, and for the period 2000-2099 from the corresponding AR4 A2 scenario 
Table II. Global and land (in parentheses) annual average reference height air temperature difference $\left({ }^{\circ} \mathrm{C}\right)$ from base period (1980-1999) and the urban, rural and urban minus rural temperature for the NWHF and WHF simulations. The urban and rural averages are for all grid cells where urban areas are resolved by the model. The AR4 A2 scenario multi-model ensemble mean (global only) is shown for reference (Meehl et al., 2007). The time slices here are the same as those used in Meehl et al. (2007) with the exception of the end of the century time slice.

\begin{tabular}{lrccc}
\hline Simulation & $\begin{array}{r}1980- \\
1999\end{array}$ & $2011-2030$ & $2046-2065$ & 2079-2098 \\
\hline NWHF & - & $0.95(1.17)$ & $1.95(2.41)$ & $3.40(4.21)$ \\
WHF & - & $0.94(1.11)$ & $1.97(2.46)$ & $3.41(4.22)$ \\
NWHF urban & 17.92 & 18.89 & 19.88 & 21.26 \\
NWHF rural & 16.80 & 17.79 & 18.81 & 20.23 \\
NWHF & 1.12 & 1.10 & 1.07 & 1.03 \\
urban-rural & & & & \\
WHF urban & 17.97 & 18.89 & 20.00 & 21.37 \\
WHF rural & 16.79 & 17.74 & 18.88 & 20.30 \\
WHF & 1.18 & 1.15 & 1.12 & 1.08 \\
urban-rural & & & & \\
Meehl et al. & - & 0.64 & 1.65 & $3.13^{\mathrm{a}}$ \\
(2007) & & & & \\
\hline
\end{tabular}

${ }^{\text {a }}$ For the period 2080-2099.

(high emissions) CCSM3 ensemble member. The period 1941-1979 serves as a spin-up period that is sufficient to minimize the influence of initial conditions on the results (Oleson et al., 2008c). For reference, the AR4 A2 scenario results in a globally averaged surface temperature increase of $3.13^{\circ} \mathrm{C}$ for the period 2080-2099 AR4 multimodel ensemble mean compared to the period 1980-1999 base period (Meehl et al., 2007) (Table II). The first simulation designated as no waste heat flux (NWHF) uses prescribed minimum/maximum temperatures from the urban dataset to maintain realistic interior building temperatures thereby simulating HAC. The second simulation includes waste heat fluxes (WHF) from HAC as described in Appendix. Urban fractional area is constant throughout the simulations because urban datasets are only available for the present day. Furthermore, changes in population, urban structure, anthropogenic heat (other than directly caused by urban air temperature changes in the model) and adaptation and mitigation measures in response to climate change are not considered.

\section{Results and discussion}

\subsection{Urban heat island characteristics}

\subsubsection{Spatial and temporal aspects}

The air temperature in the UCL is used to assess the simulated urban heat island by comparing it with the temperature from the 'rural' surfaces in the model. The rural temperature is defined as the area-average of the reference height PFT air temperatures (including the bare soil type) in the grid cell. Figure 3 shows the presentday (1980-1999) urban heat islands produced by the model for annual, DJF (December, January, February) and JJA (June, July, August) climatology for the NWHF simulation. A significant number of model grid cells have an urban landunit because a very small minimum threshold of $0.1 \%$ of the grid cell by area is used to resolve urban areas. However, because the urban fractions are so small in these coarse resolution simulations, there is minimal effect on the large-scale climate (e.g. surface air temperature and precipitation) (not shown). Also, note that individual cities are not necessarily resolved at this resolution; rather the urban areas are a highly averaged representation of any number of individual cities.

The temperature scale in Figure 3 emphasizes that the heat island is positive nearly everywhere in both seasons with a magnitude ranging from near-zero to $4{ }^{\circ} \mathrm{C}$. To put these urban heat islands in perspective, the average annual heat island (average over all urban areas resolved in the model) simulated by the model for the period $1980-1999$ is $1.12^{\circ} \mathrm{C}$. This is $57 \%$ of the global warming due to greenhouse gases simulated by the model for the mid-century period $2046-2065\left(1.95^{\circ} \mathrm{C}\right)$ and about $46 \%$ of the warming over global land (Table II).

The causes of the heat island in the model can be ascertained by comparing the diurnal cycle of urban and rural areas. Figure 4 shows a comparison of the annual diurnal cycle of urban, rural, and grid cell averaged temperature and energy balance for a single grid cell encompassing the New York City region. The grid cell average temperature is minimally affected by the urban surfaces because of the small fraction of urban cover. However, there are significant differences in the diurnal cycle between urban and rural land cover types. The urban heat island is persistent at all hours of the day but is most apparent beginning in late afternoon/early evening, reaching a peak of nearly $3{ }^{\circ} \mathrm{C}$ at $0100 \mathrm{Z}$ (about $8 \mathrm{pm}$ local time). The urban daily minimum temperature is substantially warmer than the rural, whereas the difference between urban and rural maximum temperature is less than $1{ }^{\circ} \mathrm{C}$. Thus, the urban diurnal temperature range is reduced compared to rural by about $1.5^{\circ} \mathrm{C}$.

Urban net radiation is similar to rural net radiation at night indicating that lower urban emissivity is likely compensating somewhat for higher urban surface temperature as both urban and rural experience the same downward long-wave radiation (Figure 4). In daytime, urban net radiation is somewhat lower than rural primarily due to higher urban albedo and increased long-wave radiation loss due to warmer surface temperatures (not shown). The partitioning of this radiation into turbulent and storage heat fluxes is quite different between urban and rural surfaces and is the cause of the differences in air temperature. The urban area stores more heat during the day and releases it later in the day and at night, thereby maintaining a near-zero or positive sensible heat flux at all times. 

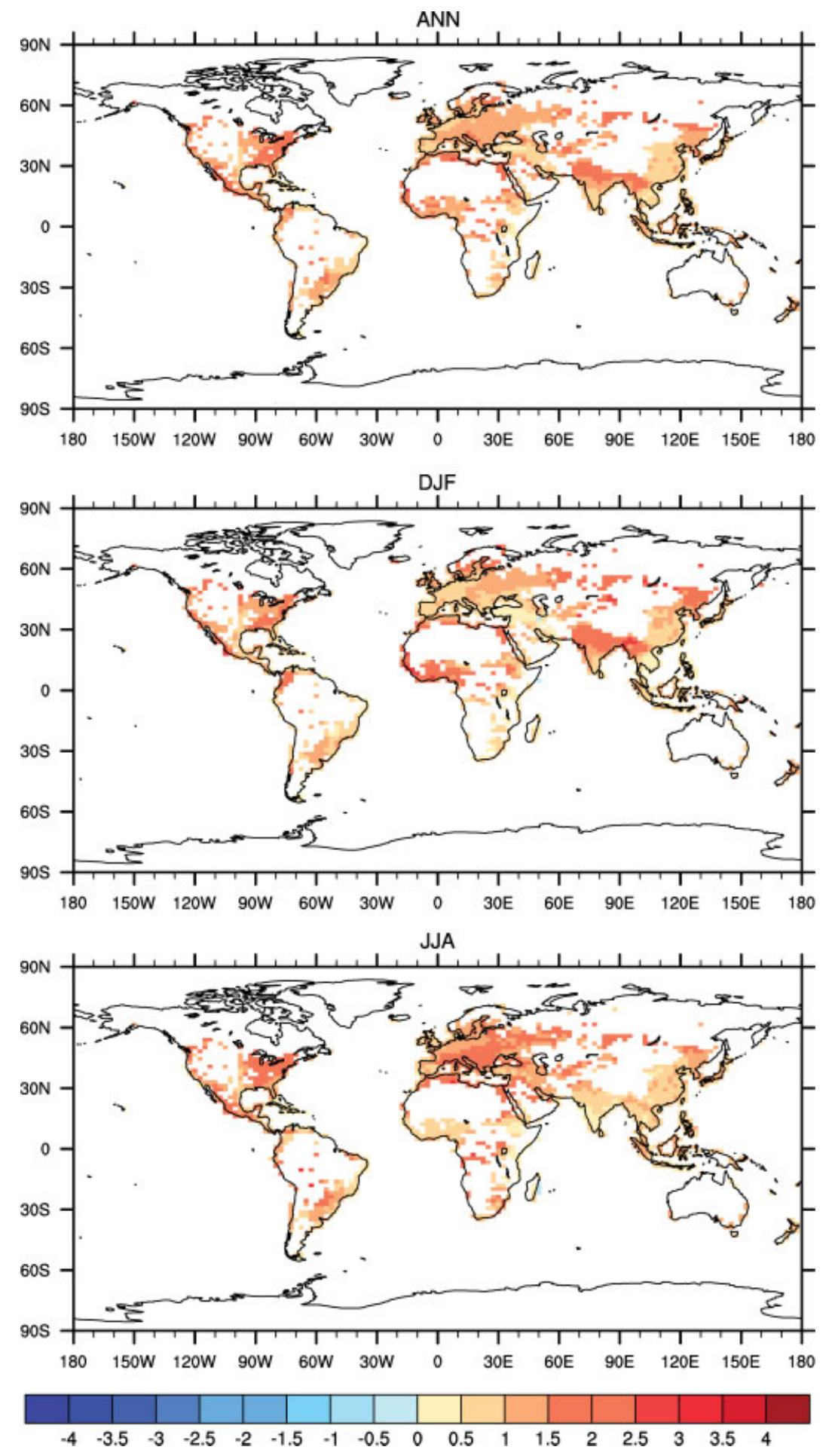

Figure 3. 1980-1999 Annual, DJF(December, January, February) and JJA (June, July, August) climatology of urban minus rural reference height air temperature (urban heat island) for the NWHF simulation $\left({ }^{\circ} \mathrm{C}\right.$ ). Land areas displayed in white are grid cells that have zero urban fractions in the model. This figure is available in colour online at wileyonlinelibrary.com/journal/joc

The urban latent heat flux is less than half the rural during daytime due to the presence of impervious surfaces. This also contributes to warmer urban temperatures.

Warmer urban minimum temperatures and a reduction in the diurnal temperature range is a persistent feature in the global simulation (Figure 5). Urban minimum temperatures are up to $5^{\circ} \mathrm{C}$ warmer than rural, whereas urban maximum temperatures are at most $2^{\circ} \mathrm{C}$ warmer.
Compared to rural areas, urban areas have a smaller diurnal temperature range by an average of $1{ }^{\circ} \mathrm{C}$. These urban features are consistent with results from Oleson et al. (2008b) and are supported in a qualitative sense by observations.

Figure 3 clearly shows that there are large spatial and seasonal variations in the heat island. These variations are caused by differences in urban morphological (e.g. 
Air Temperature

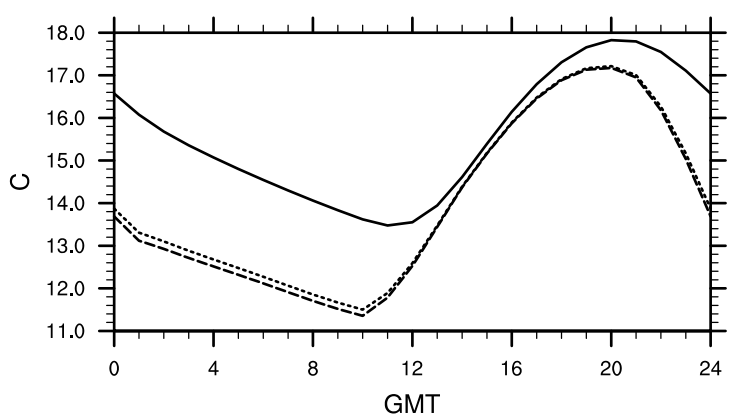

Sensible Heat

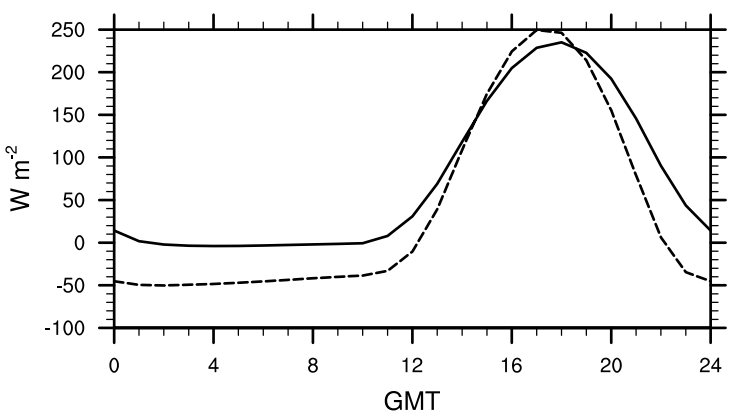

Storage

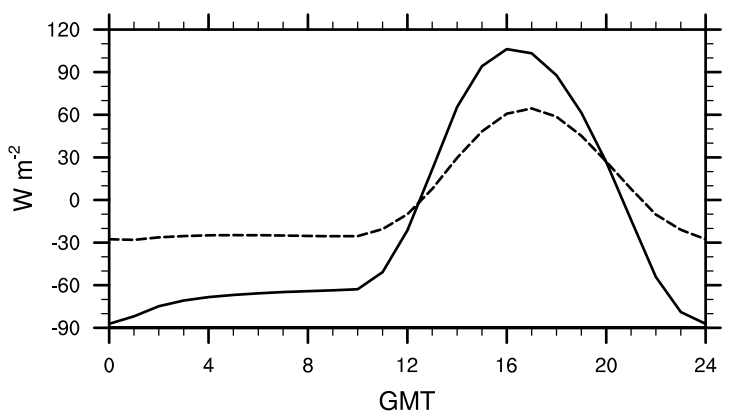

Net Radiation

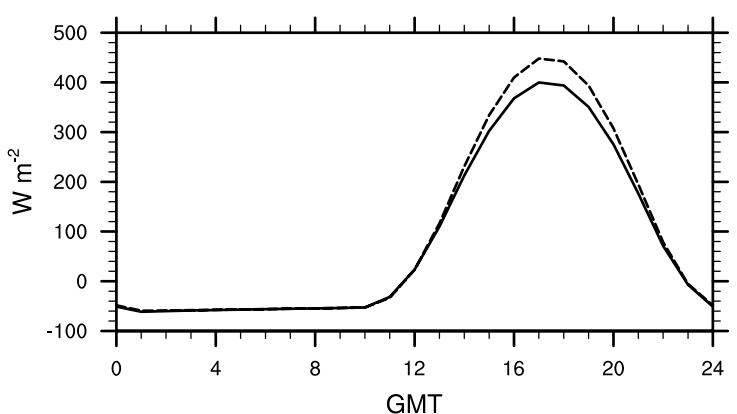

Latent Heat

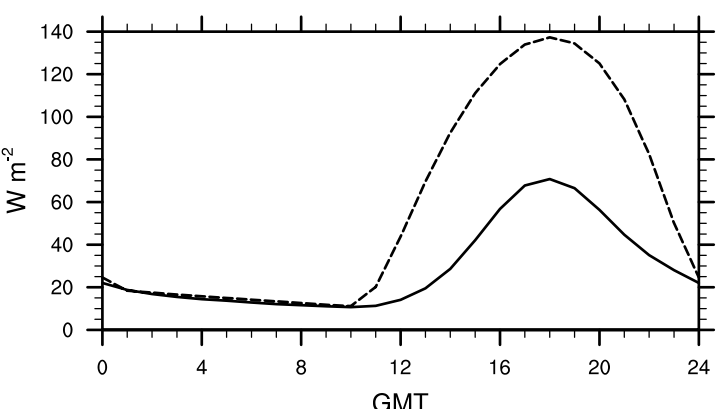

Figure 4. Annual climatological (1980-1999) diurnal cycle of urban, rural and grid cell average (shown only for air temperature for clarity) air temperature, and urban and rural energy balance for a grid cell located at $40.7^{\circ} \mathrm{N}, 287.5^{\circ} \mathrm{E}$ for the NWHF simulation. The land fraction of the grid cell is composed of $6 \%$ urban and $94 \%$ rural.

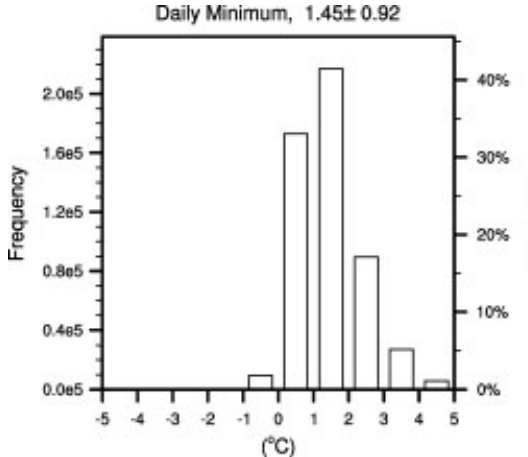

("C)

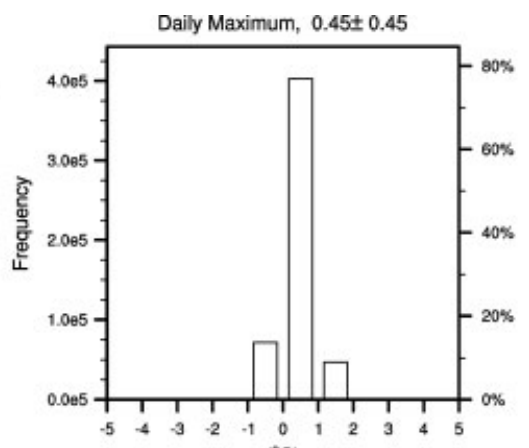

$\left({ }^{\circ} \mathrm{C}\right)$

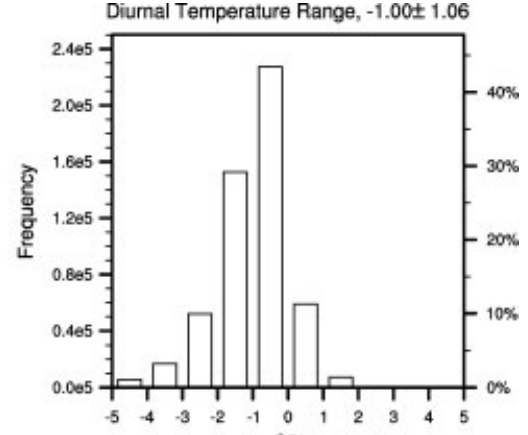

( $\left.{ }^{\circ} \mathrm{C}\right)$

Figure 5. Climatology (1980-1999) of daily urban minus rural minimum, maximum and diurnal range in air temperature for all grid cells containing urban for the NWHF simulation. Total number of data points in each histogram is 523410 (365 days $\times 1434$ grid cells with urban). Numbers indicate the average plus/minus one standard deviation.

building height to street width ratio), radiative (e.g. emissivity and albedo) and thermal (e.g. thermal conductivity and heat capacity) properties, the contrast between these urban properties and the surrounding soil and vegetation properties, and different responses of urban and rural areas to various climate regimes. For example, Oleson et al. (2008b) found that the heat island varies with height to width ratio, pervious fraction, anthropogenic heat flux 
Air Temperature

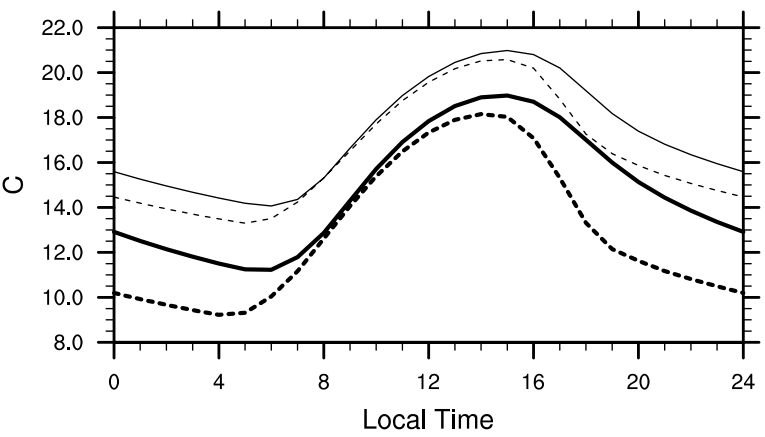

Sensible Heat

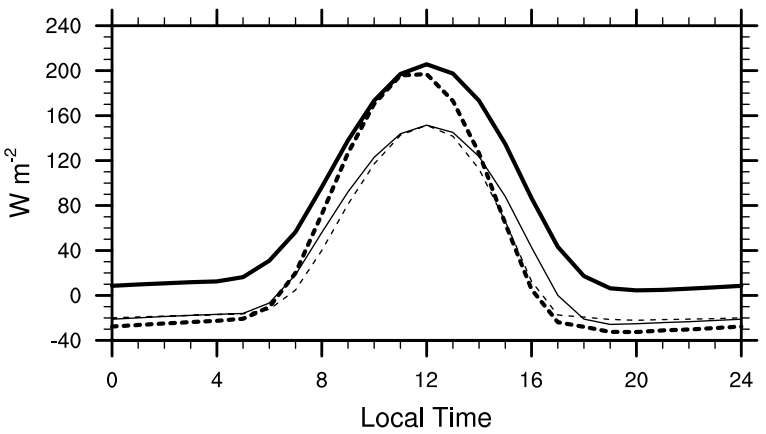

Storage

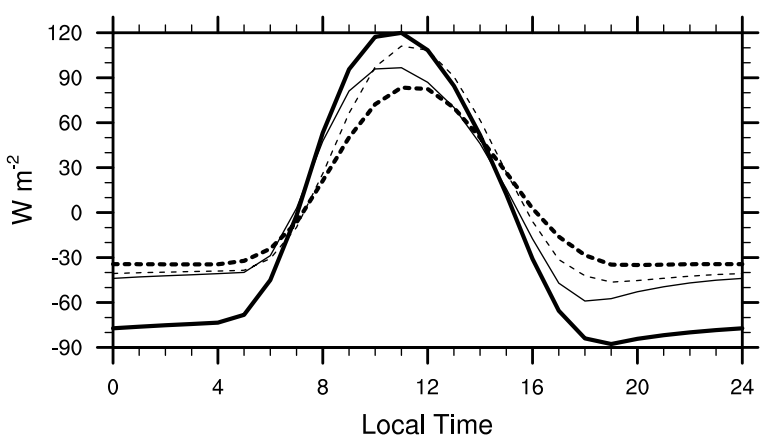

Net Radiation

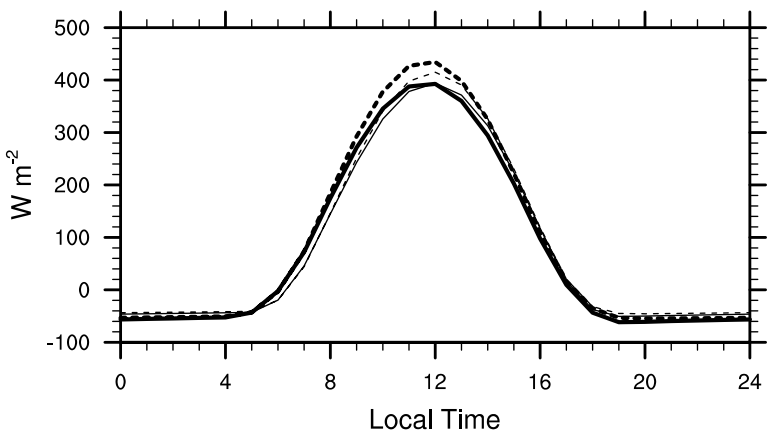

Latent Heat
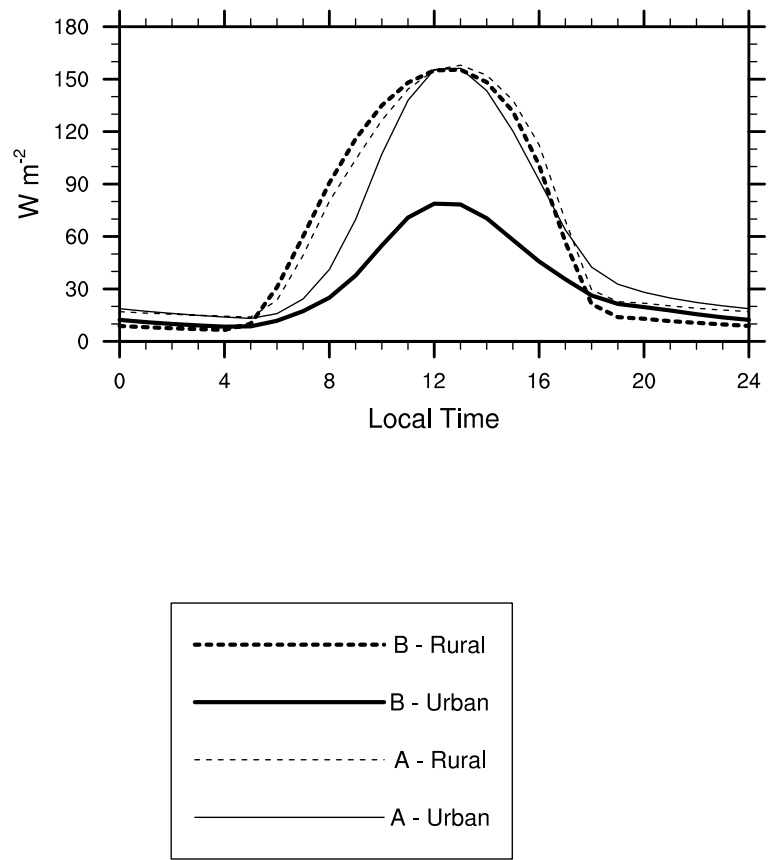

Figure 6. Annual climatological (1980-1999) diurnal cycle of urban and rural air temperature and energy balance for two grid cells in the NWHF simulation. Grid cell A (thin lines) is located in Southeast China at $29.4^{\circ} \mathrm{N}, 115^{\circ} \mathrm{E}$ and grid cell B (thick lines) is located in the eastern United States at $38.8^{\circ} \mathrm{N}, 282.5^{\circ} \mathrm{E}$.

and the type of rural surface. This behaviour is confirmed by many other studies [e.g. Oke, 1981 (height to width ratio), Upmanis et al., 1998 (pervious fraction), Ichinose et al., 1999 (anthropogenic heat flux), Hawkins et al., 2004 (type of rural surface)]. It is difficult to find robust explanations for all of the variability in the heat island shown in Figure 3 because of the large number of independent variables involved. However, some insight into model behaviour can be gained by focusing on some regions where the spatial or seasonal contrast in the heat island is the greatest.

As an example of spatial variation in the heat island, consider that the annual mean heat island in southeast China is generally much less than in the eastern United States (Figure 3). Figure 6 contrasts the annual diurnal cycle of air temperature and energy balance for a grid cell in southeast China (A) with one in the eastern United States (B), where the annual mean heat islands are 0.8 and $1.9^{\circ} \mathrm{C}$, respectively. The eastern US grid cell includes the cities of Washington DC and Baltimore, whereas the largest city in grid cell A is Nanchang. Both grid cells have urban heat islands that reach a maximum at night-time. For grid cell $\mathrm{A}$ in China, the urban and rural sensible and storage heat fluxes are quite similar to each other resulting in a relatively small heat island. In contrast, in grid cell $\mathrm{B}$, the urban storage heat flux has much larger amplitude than the rural storage, which results in a larger heat island. Thus, it is the magnitude of urban to rural contrast in storage that is determining the magnitude of the heat island, particularly at night. In grid cell $\mathrm{B}$, the urban latent heat flux is much less than the rural flux, whereas grid cell A has more similar urban and rural latent heat flux. This likely contributes to the larger daytime heat island in grid cell B as more of the available energy goes into warming the surface. 
Air Temperature

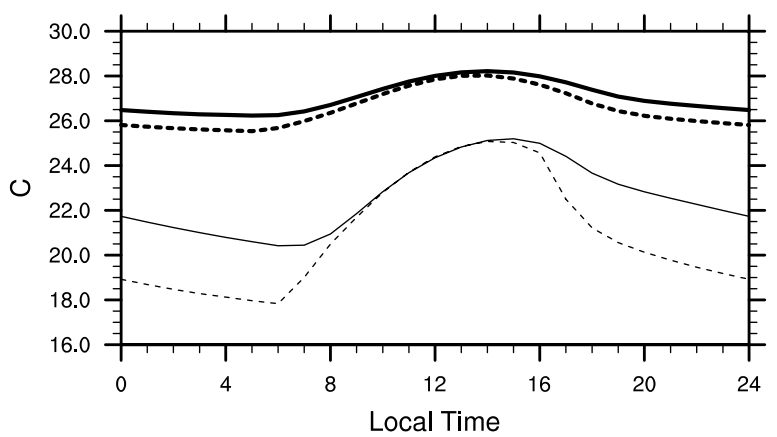

Sensible Heat

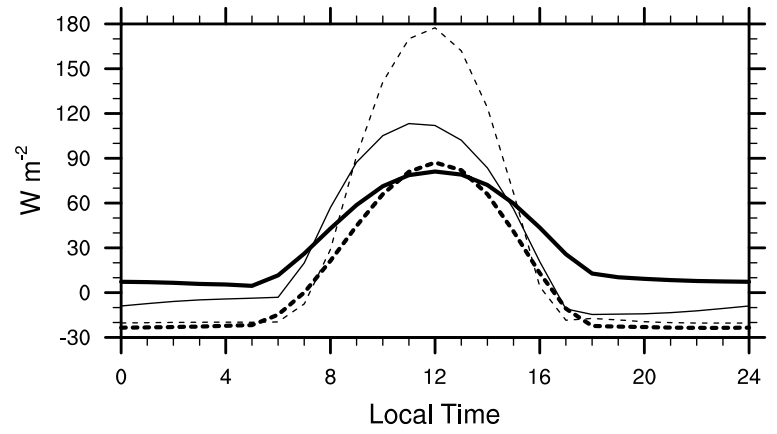

Storage

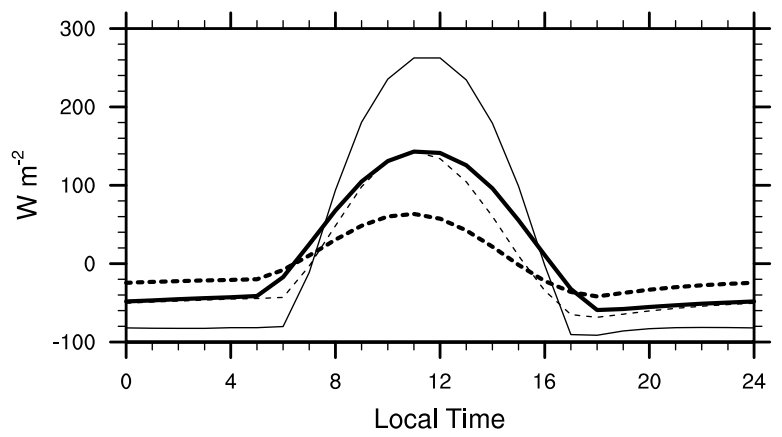

Net Radiation

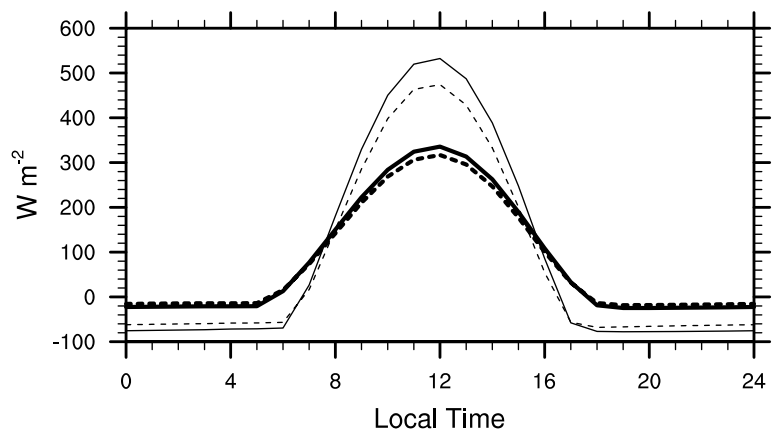

Latent Heat

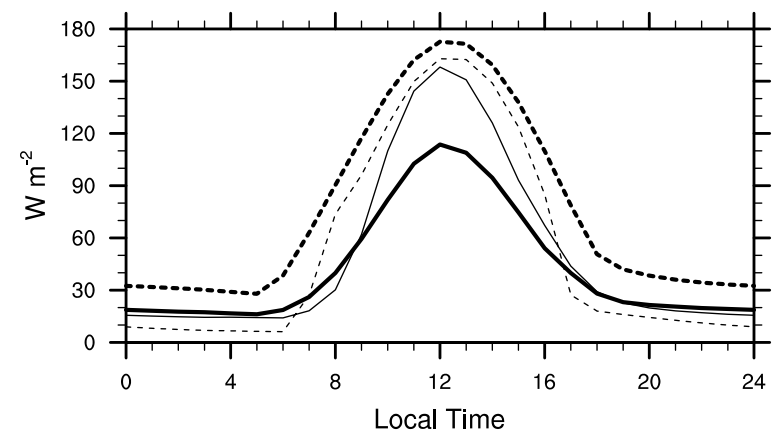

Figure 7. DJF and JJA climatological (1980-1999) diurnal cycle of urban and rural air temperature and energy balance for a grid cell in India $\left(19.9^{\circ} \mathrm{N}, 72.5^{\circ} \mathrm{E}\right)$ for the NWHF simulation.

The greater heat island in India in northern winter compared to summer is an instructive example of large temporal variability in the heat island (Figure 3). Figure 7 contrasts the DJF and JJA diurnal cycle of temperature and energy balance for a grid cell in India that includes the city of Mumbai. Although urban and rural temperatures are similar during the day in both seasons, the urban to rural contrast in night-time temperature is quite different in the two seasons. In particular, the rural temperature cools and warms much faster in winter than summer. Because of the monsoon, this part of India has a pronounced seasonal cycle in simulated climate that is characterized by high solar radiation $\left(196 \mathrm{~W} \mathrm{~m}^{-2}\right)$ and low precipitation $\left(0.5 \mathrm{~mm} \mathrm{day}^{-1}\right)$ in winter and lower solar radiation $\left(126 \mathrm{~W} \mathrm{~m}^{-2}\right)$ and substantially higher precipitation $\left(15.0 \mathrm{~mm} \mathrm{day}^{-1}\right)$ in summer. As a result, daytime net radiation in winter is much larger than in summer. This drives larger urban and rural sensible and storage heat fluxes in winter. However, the rural area has a larger response in sensible heat than storage in contrast to the urban area; thus the rural area has a more dynamic air temperature in winter than in summer. Similar seasonal behaviour in the heat island is found in the Sahel (Figure 3), which has a seasonal cycle in precipitation, although smaller in amplitude than that in India.

The urban latent heat flux is a large part of the energy balance in both seasons (Figure 7). The medium density urban representation in the urban surface dataset prescribes a very large pervious fraction in India in general $(>0.9)$ and thus the urban areas have the potential to produce large latent heat fluxes.

\subsubsection{Maximum heat islands}

Maximum heat islands, which generally occur at night (e.g. Figure 4), are of interest because of their potential impacts on human health. For example, warmer urban night-time temperatures may exacerbate the severity of 
heat waves because they limit relief from heat stress during daytime (e.g. Changnon et al., 1996). Observations of maximum heat islands are generally reported as a single manifestation of a particular weather event (e.g. Oke and East (1971) reported a maximum heat island of $12{ }^{\circ} \mathrm{C}$ for the city of Montreal under calm, cold nighttime conditions). The maximum heat island produced in both simulations during any day of the period 1980-1999 is about $18^{\circ} \mathrm{C}$. However, a single event may not be a robust feature in the climate simulations, and Figure 8 shows the 1980-1999 climatology of the maximum and daily average maximum heat island for the NWHF simulation. Both the maximum and daily average maximum heat island are highly correlated with the annual average heat island (Figure 3) $(r=0.84$ and $r=0.91$, respectively), indicating that these are persistent features in time. For example, the largest maximum heat islands generally occur in regions with the largest average heat island including the eastern United States, southern Europe, northern India and Indochina. The largest maximum and daily average maximum heat islands are 8.2 and $5.3{ }^{\circ} \mathrm{C}$, respectively, and occur in northern winter in northwestern Indochina. Averaged over all urban areas, the maximum and daily average maximum heat islands are roughly 3.5 and 2 times larger than the average heat island for present day (Table II). These large factors imply that these measures of heat islands, in addition to the average heat island, should be considered when assessing the impact of cities on climate and human health.

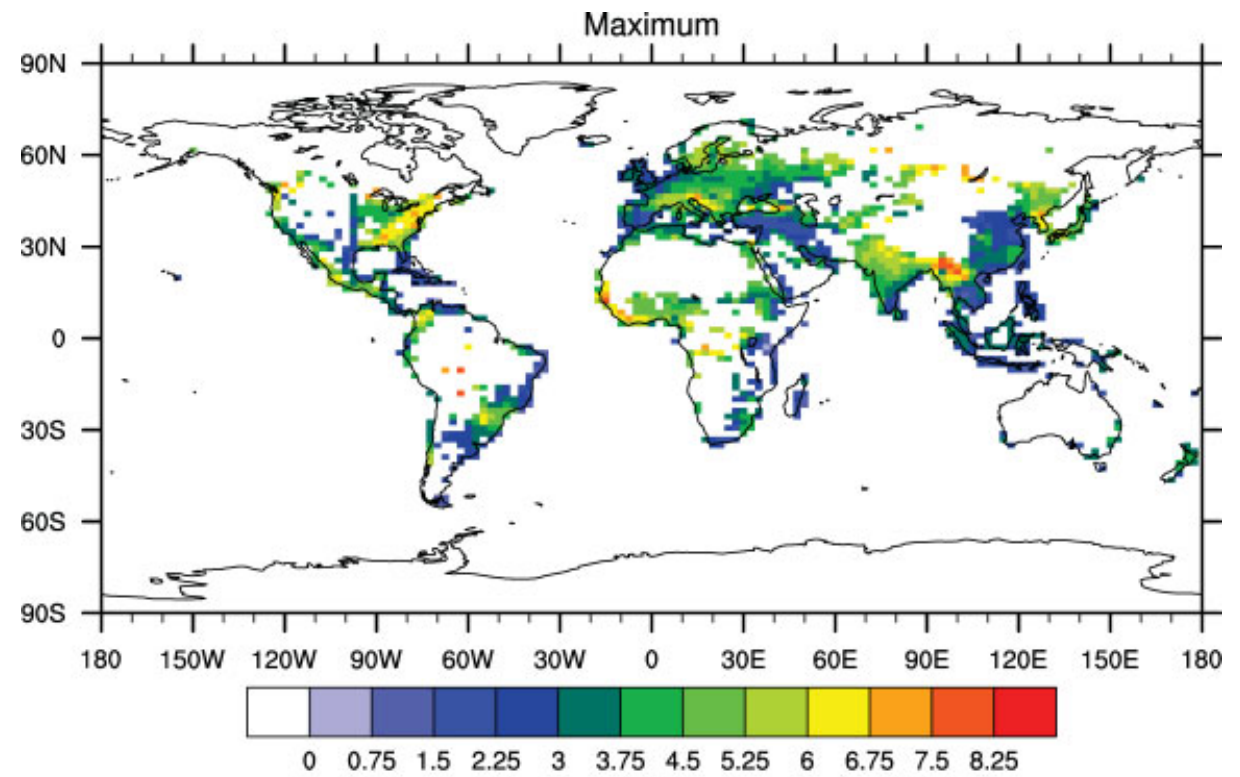

Daily Average Maximum

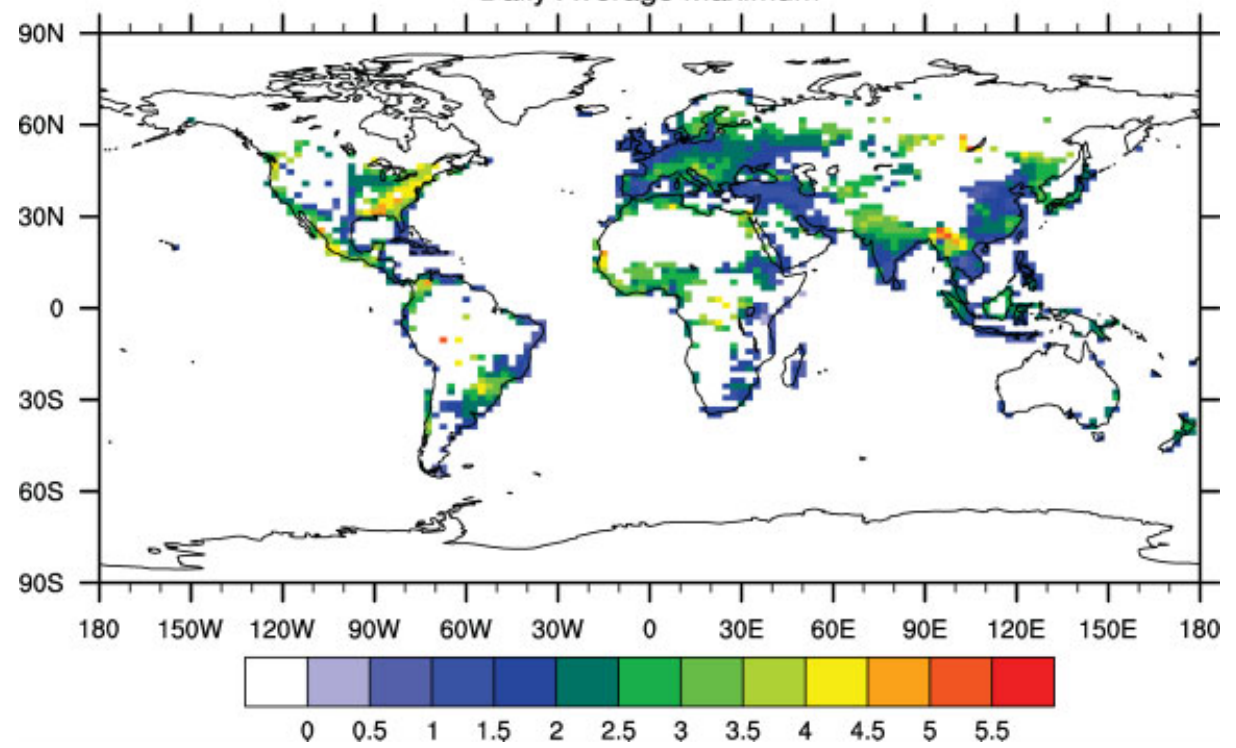

Figure 8. Annual climatology (1980-1999) of maximum and daily average maximum urban heat island for the NWHF simulation $\left({ }^{\circ} \mathrm{C}\right)$. The maximum heat island is calculated as the maximum urban minus rural difference for any hour in each year and then averaged over the climatological period. The daily average maximum heat island is the maximum heat island for each day averaged over all days in the year and all years in the climatological period. This figure is available in colour online at wileyonlinelibrary.com/journal/joc 


\subsubsection{Future heat islands}

In both the NWHF and WHF simulations, the contrast between urban and rural air temperature decreases slightly in a warmer 21 st-century climate (Table II). In the NWHF simulation, the rural areas warm by $3.43^{\circ} \mathrm{C}$ from 1980-1999 to 2079-2098, whereas urban areas warm by $3.34^{\circ} \mathrm{C}$. Figure 9 shows the spatial pattern of changes in urban, rural and urban minus rural air temperature between the periods 2079-2098 and 1980-1999. Both urban and rural areas warm substantially in response to greenhouse gas induced climate change, but generally the rural areas warm more and reduce the urban to rural contrast. Although these differences are only a few tenths of a degree, they are statistically significant for a significant fraction of the grid cells (in DJF and JJA, the differences are significant in 82 and $76 \%$ of the grid cells, respectively, assessed using a Student's $t$-test at a confidence level of 99\%).

In northern winter, there is some latitudinal dependence of the decreased temperature contrast with areas north of $30^{\circ} \mathrm{N}$ experiencing the largest decrease (Figure 9). In these regions, heating of the buildings is required to maintain internal temperatures within the comfort levels prescribed by the urban dataset. An example of how this affects the urban to rural contrast in temperature is shown in Figure 10. In winter, when urban and rural net radiation and latent heat fluxes are similar, the urban area has a larger sensible heat flux that is supported by the building heat resulting in a larger release of heat from the surface than the rural area (the negative urban minus rural ground heat flux in Figure 10). In a warming climate, less heat is required to keep the buildings warm. This reduces the heat released from the urban surface thereby reducing sensible heat flux and decreasing the urban to rural temperature contrast. In other months, the building heat is not as important and the contrast in air temperature is more similar across future time slices.

South of $30^{\circ} \mathrm{N}$ in northern winter and in northern summer in general, building heat is not important in the energy budget (not shown), yet most regions still show a reduced urban to rural contrast in air temperature (Figure 9). The reduction in contrast is highly positively correlated with a decrease in the urban minus rural minimum temperature in both seasons $(r=0.94$ for DJF, $r=0.91$ for JJA) rather than the maximum temperature (Figure 11). Thus, rural areas are warming more than urban at night. The mechanism by which this occurs is related to changes in incoming long-wave radiation. At
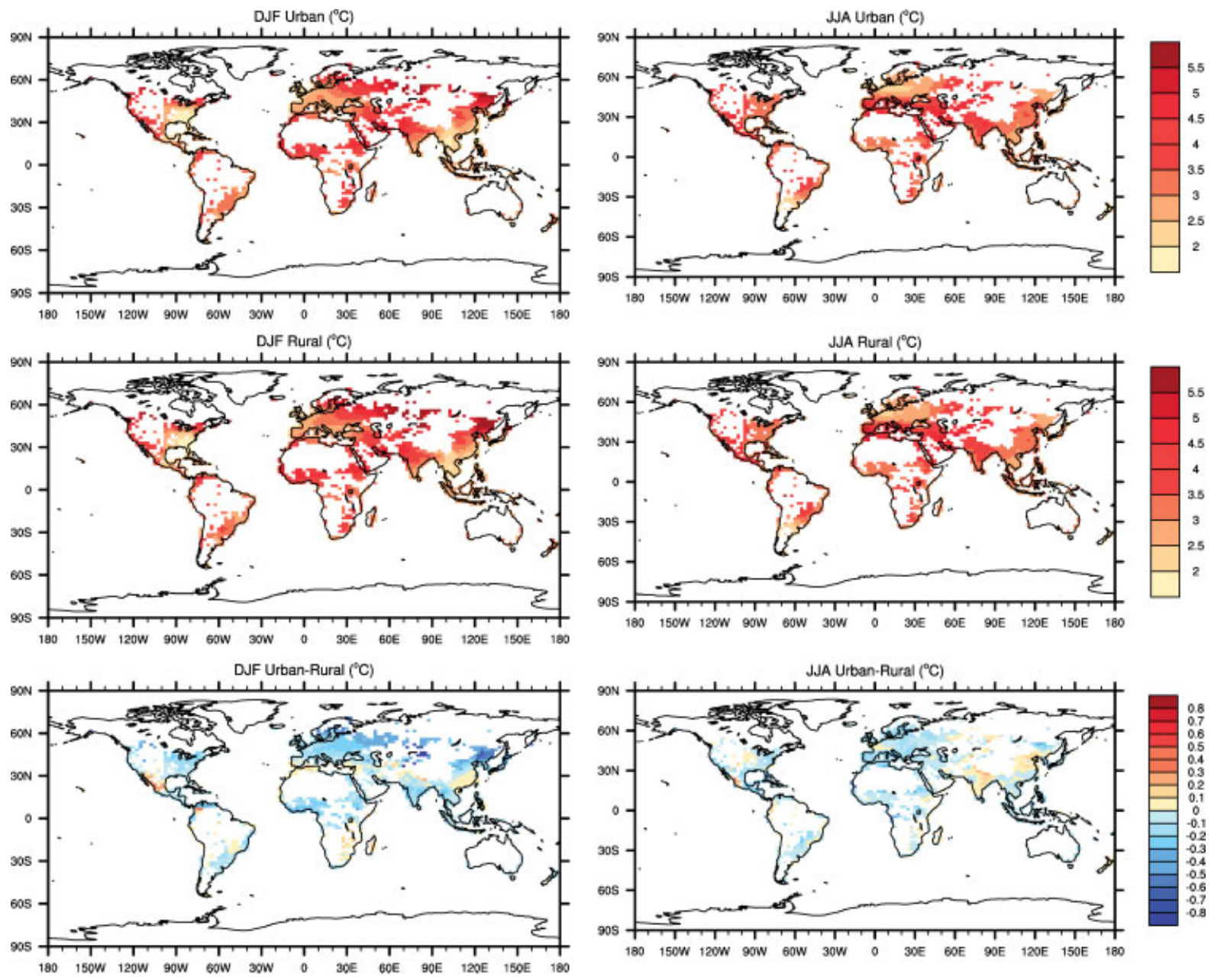

Figure 9. 2079-2098 minus 1980-1999 DJF and JJA climatology of urban, rural and urban minus rural reference height air temperature for the NWHF simulation $\left({ }^{\circ} \mathrm{C}\right)$. This figure is available in colour online at wileyonlinelibrary.com/journal/joc 

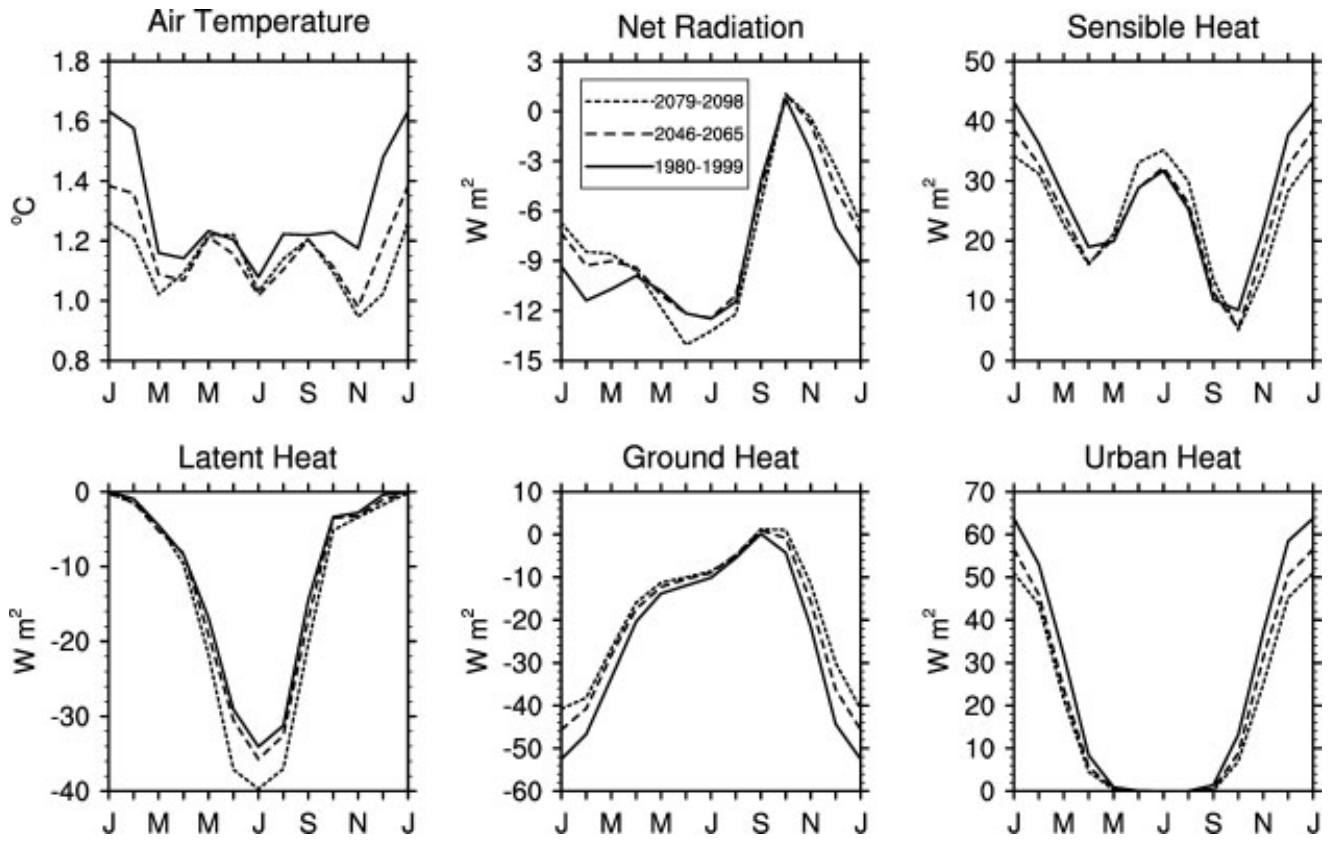

Figure 10. Seasonal cycle of urban minus rural air temperature and energy fluxes in Northeast China (averaged over $35-50^{\circ} \mathrm{N}, 118-140^{\circ} \mathrm{E}$ ) for the NWHF simulation for 1980-1999, 2046-2065 and 2079-2098. Negative urban minus rural ground heat flux implies that the urban surface is releasing more heat than the rural. Urban heat is the flux required to maintain internal building temperatures above a prescribed comfort level.

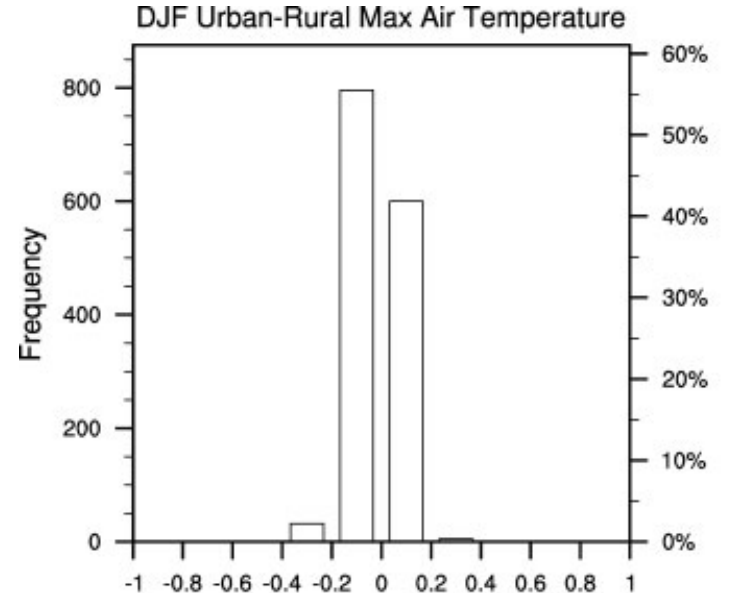

(C)

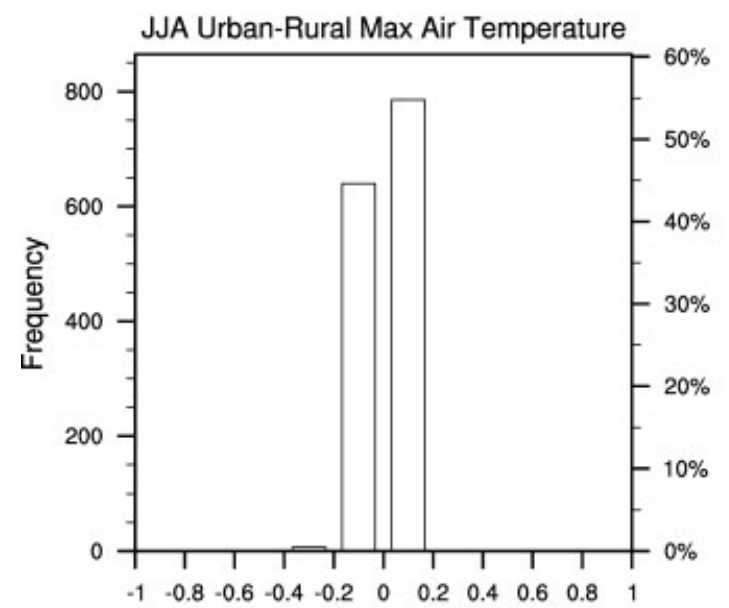

(C)

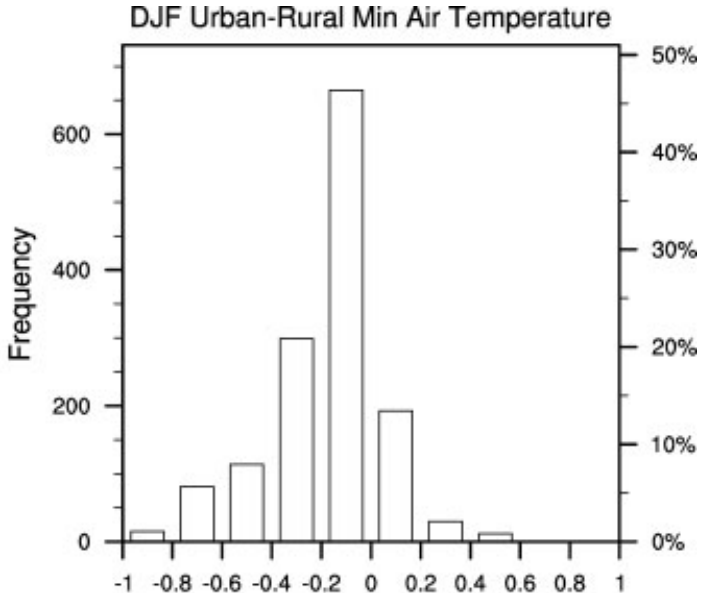

(C)

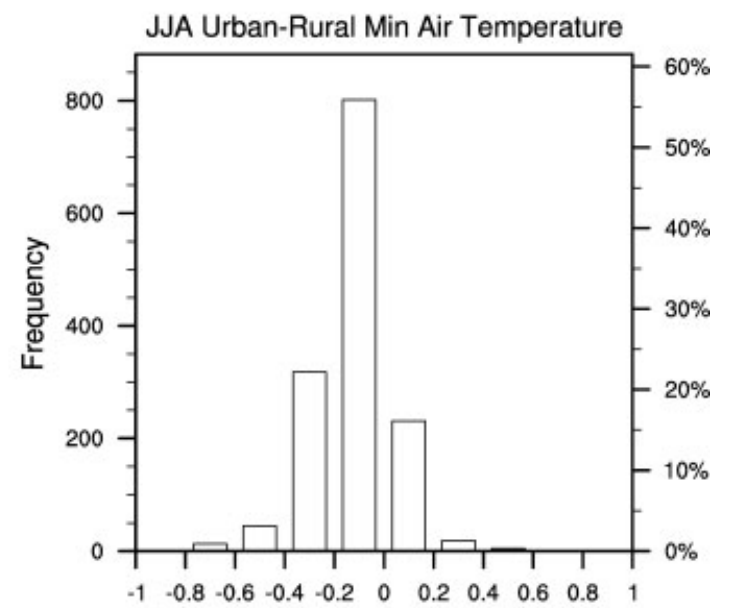

(C)

Figure 11. 2079-2098 minus 1980-1999 DJF and JJA climatology in urban minus rural maximum and minimum air temperature $\left({ }^{\circ} \mathrm{C}\right)$ for all grid cells containing urban for the NWHF simulation. Total number of data points in each histogram is 1434 . 
night, radiative forcing of the land (net radiation) is determined by the balance between incoming and outgoing long-wave radiation. There is an increase in annual mean incoming long-wave radiation over the land of about $26 \mathrm{~W} \mathrm{~m}^{-2}$ in the future time slice compared to present day, which is highly correlated with the increase in atmospheric air temperature. The larger storage capacity of urban areas and the consequent release of this stored heat at night (e.g. Figure 4) buffer the increase in long-wave radiation such that urban night-time temperatures do not warm much. In contrast, rural areas have a smaller storage term and warm more in response to the increased long-wave radiation.

To demonstrate the differential effects of increased atmospheric long-wave radiation on urban and rural areas more clearly, a pair of 10-year global offline simulations (i.e. in which CLMU is uncoupled from the atmospheric model) was conducted. The control simulation (CON) used the same configuration as the NWHF simulation except that atmospheric forcing was provided by repeating year 2000 of the dataset of Qian et al., (2006) (as implemented by Oleson et al., 2008c). A modified simulation (LW30) applied the same atmospheric forcing except that incoming long-wave

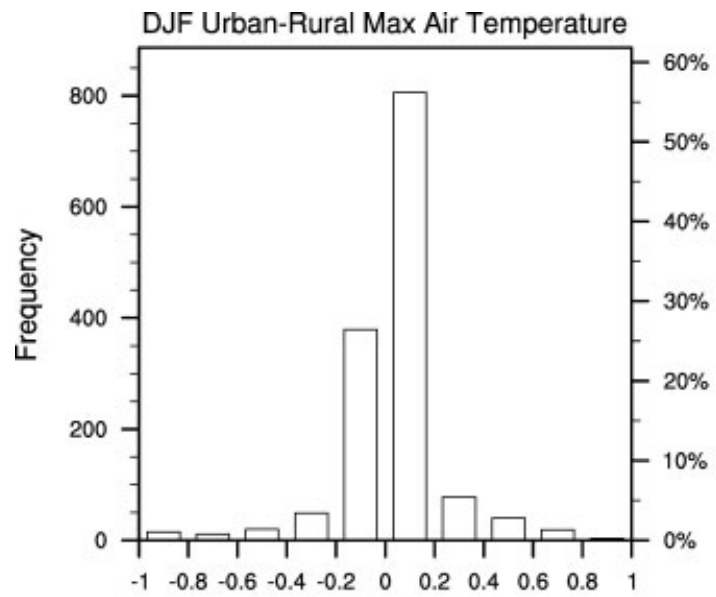

(C)

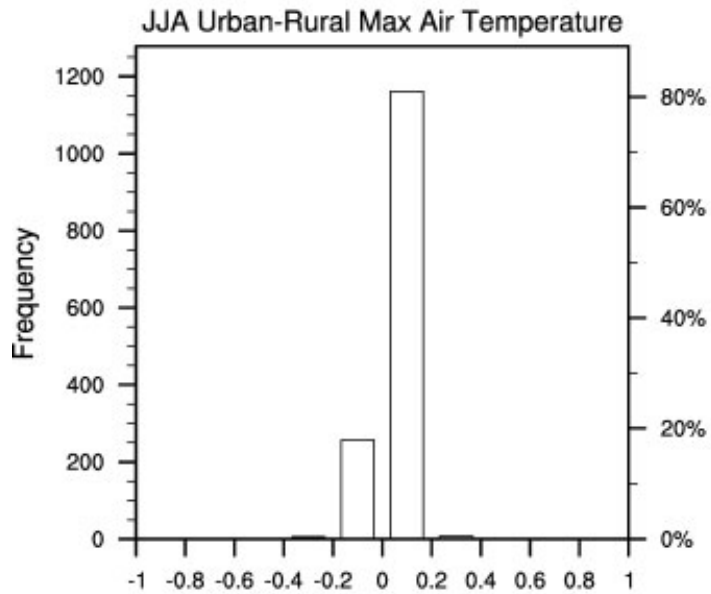

(C) radiation was increased uniformly in time and space by $30 \mathrm{~W} \mathrm{~m}^{-2}$. The first 5 years of each simulation were discarded for spin-up. The results shown in Figure 12 can be compared with Figure 11 and confirm that urban and rural areas respond differently to an increase in incoming long-wave radiation. Rural areas warm more than urban areas at night when incoming long-wave radiation is increased. The magnitude of this effect is controlled by spatial variability in the increased incoming long-wave radiation and variability in the storage capacities of urban and rural areas.

5.2. Space heating, air conditioning and the effects of anthropogenic heat flux

Table III summarizes the energy fluxes associated with heating and air conditioning for various time slices of the NWHF and WHF simulations. The WHF urban air temperature is generally slightly warmer than in the NWHF simulation depending on the time slice (Table II) because of the waste heat added as sensible heat to the canyon system (Table III). In the WHF simulation, the waste heat decreases in the future because the total HAC decreases (Table III). Note that the total waste heat in any time period is less than might be expected based

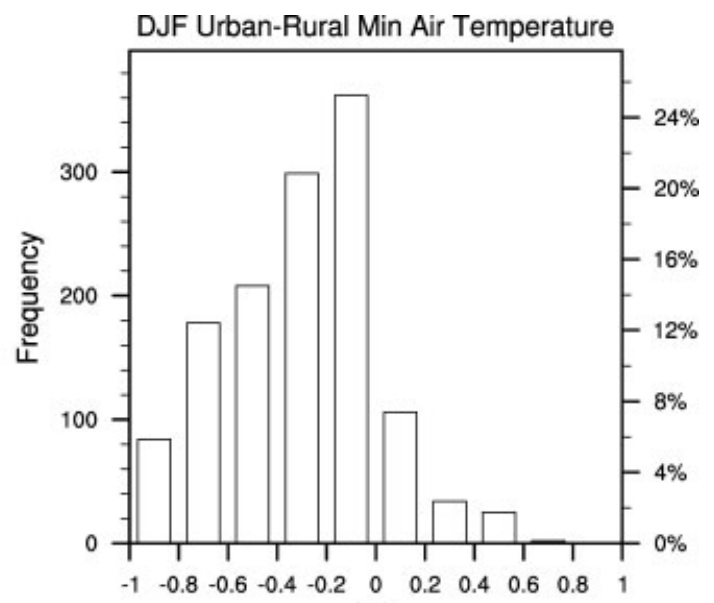

(C)

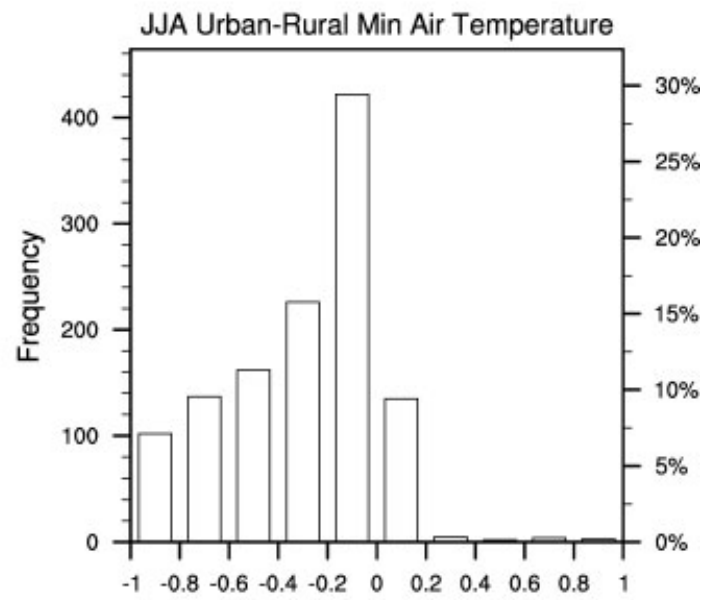

(C)

Figure 12. LW30 minus CON DJF and JJA climatology (6-10 years) of urban minus rural maximum and minimum air temperature $\left({ }^{\circ} \mathrm{C}\right)$ for all grid cells containing urban. The LW30 and CON simulations are described in the text. Total number of data points in each histogram is 1434. 
Table III. Urban air conditioning (AC), space heating (HEAT), wasteheat (WSTH), building heat (BUILD), and total anthropogenic heat flux (AHF) (all in terawatts) for the NWHF and WHF simulations. The building energy flux represents the total nonzero lower boundary flux for roofs and walls (Appendix). A negative value means energy is removed from the urban system (e.g. air conditioning is always negative). See Section 5.2 for an explanation of how AHF is calculated. Positive AHF is a source of energy from the land to the rest of the climate system, whereas negative AHF is a sink of energy.

\begin{tabular}{llcccc}
\hline & & $1980-$ & $2011-$ & $2046-$ & $2079-$ \\
& & 1999 & 2030 & 2065 & 2098 \\
\hline \multirow{2}{*}{ AC } & NWHF & -0.09 & -0.11 & -0.15 & -0.20 \\
& WHF & -0.09 & -0.12 & -0.15 & -0.22 \\
\multirow{4}{*}{ WEAT } & NWHF & 5.8 & 5.1 & 4.6 & 3.9 \\
& WHF & 5.6 & 5.0 & 4.3 & 3.7 \\
\multirow{4}{*}{ BUILD } & NWHF & 0.0 & 0.0 & 0.0 & 0.0 \\
& WHF & 4.7 & 4.4 & 4.0 & 3.6 \\
\multirow{2}{*}{ AHF } & NWHF & 0.3 & -0.4 & -0.8 & -1.6 \\
& WHF & 0.1 & -0.5 & -1.1 & -1.7 \\
& NWHF & 0.4 & -0.3 & -0.6 & -1.4 \\
& WHF & 4.9 & 4.0 & 3.1 & 2.1 \\
\hline
\end{tabular}

on the specified HAC efficiency factors because of the conservative limit placed on the maximum waste heat flux (Appendix).

In both simulations, compared to present day and under the simulation constraint of no urban growth, the energy required for air conditioning increases in a warming climate (e.g. by $120 \%$ for NWHF 2079-2098), whereas heating demand decreases (by 33\%). The energy required for heating is generally slightly less in the WHF simulation compared to NWHF because the waste heat added to the system helps to keep the urban area warm. The heating flux is much larger than the air conditioning flux because the urban datasets assume that air conditioning occurs primarily in the United States. Air conditioning is confined to a latitude band of $20^{\circ} \mathrm{N}-40^{\circ} \mathrm{N}$ until about mid-century when climate warming is sufficiently large to trigger the need for some cooling at latitudes north of $40^{\circ} \mathrm{N}$ and also in the southern tropics at $10^{\circ} \mathrm{S}-30^{\circ} \mathrm{S}$ (Figure 13). Heating demand is confined mainly to latitudes north of $30^{\circ} \mathrm{N}$ and a small amount at $30^{\circ} \mathrm{S}-40^{\circ} \mathrm{S}$, which nearly disappears by 2098 (Figure 13).

The energy added to the climate system from the urban model (the total anthropogenic heat flux in Table III) is due to the non-zero bottom boundary condition for roofs and walls, plus the absolute value of the air conditioning flux, plus the waste heat from HAC (Appendix). The nonzero boundary condition is represented by the building heat term (e.g. as shown in Table III and Figure 13). For the WHF present-day climatology (1980-1999), the anthropogenic heat flux added to the system is $4.9 \mathrm{TW}$, or $0.01 \mathrm{~W} \mathrm{~m}^{-2}$ distributed globally (Table III). Flanner (2009) estimated that in 2005, the total thermal energy released from nonrenewable sources (i.e. the heat flux due to anthropogenic activities) was about $0.028 \mathrm{~W} \mathrm{~m}^{-2}$ distributed globally. Thus, the urban model produces an anthropogenic flux in the WHF simulation that is about $36 \%$ of the total anthropogenic heat flux estimated by Flanner (2009). For comparison, the percentage of total residential energy used for space heating and air conditioning in the United States in 2005 was $37 \%$ (EIA, 2009) and the percentage used by commercial buildings in 2003 was $44 \%$ (EIA, 2008).

Calculated in this manner, the simulated anthropogenic heat flux of $0.01 \mathrm{~W} \mathrm{~m}^{-2}$ is much less than by assuming that the anthropogenic flux is the sum of heating and waste heat $\left(10.3 \mathrm{TW}\right.$ or $0.02 \mathrm{~W} \mathrm{~m}^{-2}$ distributed globally for WHF present day). This is because the building heat flux is negative (a sink of energy from the perspective of the rest of the climate system) for much of the urban area south of $30^{\circ} \mathrm{N}$ (Figure 13). In these regions, the building minimum and maximum temperature thresholds are not reached and HAC is not activated, but the bottom boundary condition is not zero. Regions with the largest energy sink are characterized by thin roofs with high thermal conductivity (e.g. metals) and walls with lower thermal conductivity (e.g. concrete). During daytime, heat from absorbed solar radiation is easily conducted through roofs into the building interior. The walls are heated by this transfer of energy, but the cooler walls also impart a cooling flux on the interior of the roof. Depending on the relative surface areas of walls and roofs and their thermal properties, the net building flux may be negative (an energy sink) or positive (an energy source).

\section{Summary and discussion}

A parameterization for urban surfaces has been incorporated into the land surface model CLM as part of the global climate model CCSM. Two global climate simulations with land and atmosphere physics active and prescribed sea surface temperatures (SST) were analysed to examine urban to rural contrasts in air temperature and energy balance in the context of the AR4 A2 emissions scenario. Present-day annual mean urban air temperatures are up to $4{ }^{\circ} \mathrm{C}$ warmer than surrounding rural areas. Night-time urban warming is much greater than daytime warming resulting in a reduced diurnal range in temperature compared to rural areas. The magnitude of the heat island as well as spatial and seasonal variability in the heat island is caused by urban to rural contrasts in energy balance and the different responses of these surfaces to the seasonal cycle of climate. In particular, it was shown that the difference between urban and rural partitioning of available energy into sensible, latent and storage heat fluxes controls these aspects of the heat island.

Both urban and rural areas warm substantially by the end of century under greenhouse gas-induced climate change. Rural areas warm slightly more than urban, particularly at night, resulting in a decrease in the urban to rural contrast. In colder climates, this is due in part to reduced demand for heating in a warming climate. Reduced building heat decreases the urban to 

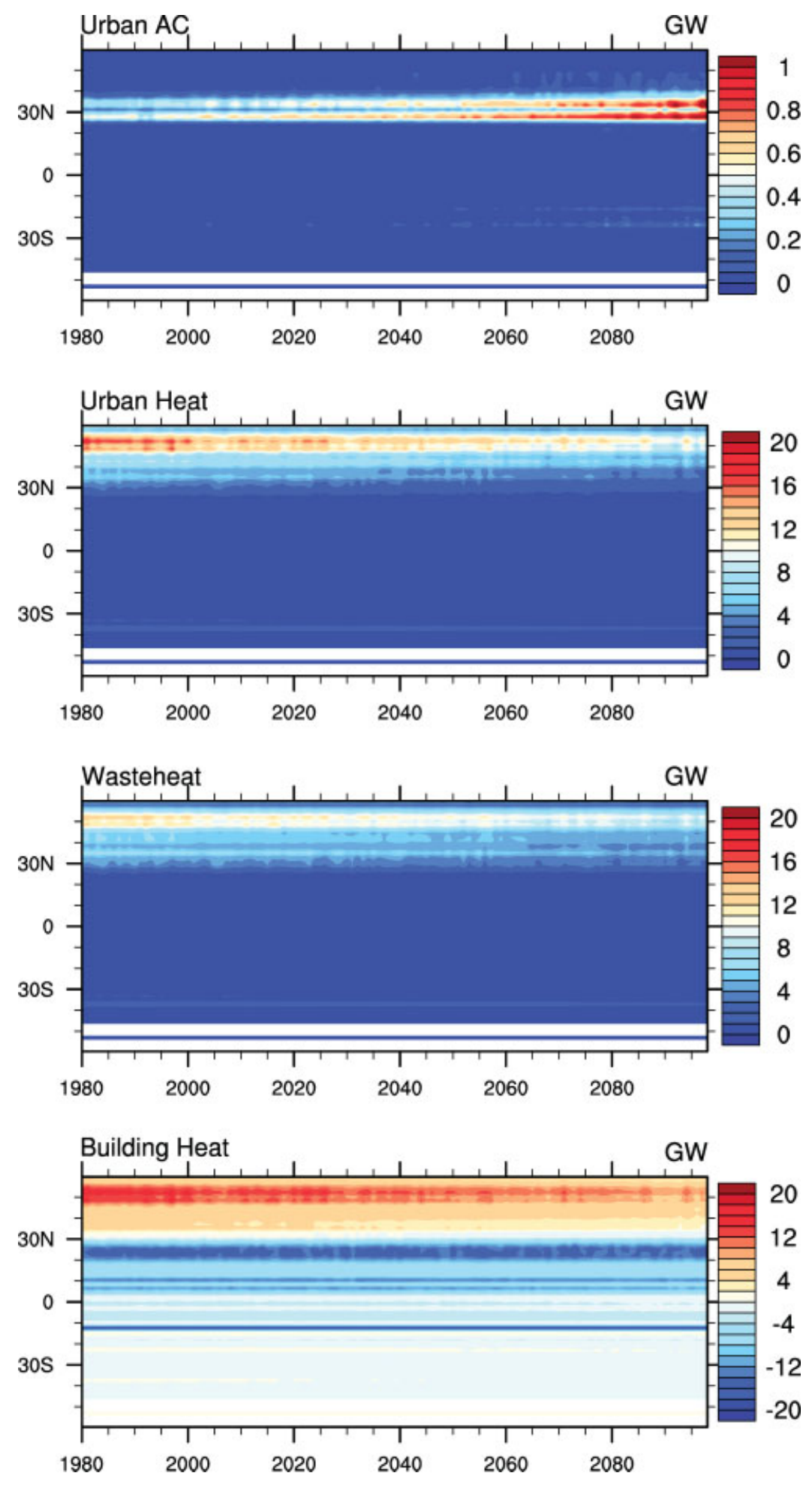

Figure 13. Zonal annual mean time series of urban air conditioning, space heating, waste heat and building heat (all in gigawatts) for the WHF simulation. This figure is available in colour online at wileyonlinelibrary.com/journal/joc

rural contrast. At other latitudes, a mechanism related to increased long-wave radiation from a warmer atmosphere is responsible. The larger storage capacity of urban areas buffers the increase in long-wave radiation such that urban night-time temperatures warm less than rural areas. Anthropogenic heat flux from space heating and air conditioning processes adds about $0.01 \mathrm{~W} \mathrm{~m}^{-2}$ of heat distributed globally, which results in a small increase in the heat island. Under the simulation constraints of no changes in urban form or density, heating demand decreases and cooling demand increases resulting in a net decrease in energy demand by the end of the century.

The inherently coarse spatial resolution of global climate simulations implies that certain features of urban heat islands may not be captured. In particular, mesoscale 
phenomenon, such as local wind systems created by pressure gradients between urban and rural surfaces (i.e. the urban heat island circulation), are not resolved in these simulations. The urban heat island circulation has been shown to have some effect on heat island temporal and spatial dynamics under certain conditions by transporting sensible heat between rural and urban areas (Haeger-Eugensson and Holmer, 1999; Hidalgo et al., 2008). Similarly, heat islands in different but adjacent cities may interact on occasion through advection so as to increase the heat island in the downwind city (Zhang et al., 2009). This implies that the quantitative model results should be interpreted with caution for geographic locations where mesoscale circulations are an important and persistent control on the urban heat island.

Another inherent limitation of these global climate simulations is that atmospheric forcing (e.g. long-wave radiation) is prescribed identically over rural and urban surfaces that are within the same grid cell. The atmospheric air over urban surfaces may have different characteristics from air over rural surfaces. For example, urban air is generally more polluted than rural air such that downwelling solar radiation may be lower and long-wave radiation may be higher over urban areas (Oke, 1987). These different characteristics of urban and rural air are not accounted for in the current modelling framework.

In terms of future climate change in urban areas, a weakness of these simulations is that the urban areas are static. In the future, urban areas are expected to increase in size, changes in urban form are inevitable, and the global population experiencing urban climates is expected to increase. These changes will have significant effects on urban properties as well as energy consumption. Development of land cover change datasets, for example the ones currently being developed for AR5, traditionally focuses on land cover change between vegetated types (e.g. conversion of forest to cropland). There is a need to expand this to include the replacement of vegetation with built surfaces.

Just as there is significant spatial and temporal variability in the heat island globally, there is also large variability within the city itself. Currently, urban areas in the model are a highly spatially aggregated representation of cities or several cities. Furthermore, the urban density class in these simulations is almost exclusively medium density which neglects the areas that may have the largest heat islands (high density and tall building district). This representation could be improved upon by separately modelling the different density classes within the urban areas as separate landunits within the CLM subgrid hierarchy. These density classes are likely to be more relevant in distinguishing between the climates where people work and where people live.

This study shows that there are significant differences between urban surfaces and the vegetated/soil surfaces typically represented in climate models. This has implications for the climate that the majority of people experience, both now and in the future. Climate models need to begin to account for urban surfaces as an integral part of investigating the impact of climate change on the land surface and thus human population.

\section{Appendix}

A.1. Space heating, air conditioning and waste heat fluxes

The second law of heat conduction in one-dimensional form is solved for each urban column. The specific solution depends on the type of urban surface. The solution for pervious and impervious canyon floors follows the solution for CLM soils (Oleson et al., 2008c) where the equation is solved numerically for a tenlayer column with up to five overlying layers of snow with boundary conditions of $h$ as the heat flux into the surface layer and zero heat flux at the bottom of the column. The bottom boundary condition for roof and sunlit and shaded walls is a nonzero flux governed by prescribed controls on the internal building temperature. The equations are solved using the Crank-Nicholson method resulting in a tridiagonal system of equations.

The net heat flux $h$ into each urban surface $\mathrm{u}$ is

$$
h_{\mathrm{u}}=\vec{S}_{\mathrm{u}}-\vec{L}_{\mathrm{u}}-H_{\mathrm{u}}-\lambda E_{\mathrm{u}}+H_{\text {wasteheat }, \mathrm{u}}+H_{\text {aircond,u }}
$$

where, $\vec{S}_{\mathrm{u}}$ is the absorbed solar radiation, $\vec{L}_{\mathrm{u}}$ is the net long-wave radiation (positive away from the surface) and $H_{\mathrm{u}}$ and $\lambda E_{\mathrm{u}}$ are the sensible and latent heat flux. The terms $H_{\text {wasteheat, u }}$ and $H_{\text {aircond,u }}$ are the waste heat from HAC and heat removed by air conditioning, applied only to the pervious and impervious road.

$$
\begin{aligned}
H_{\text {waste heat,prvrd }} & =H_{\text {waste heat,imprvrd }}=\frac{H_{\text {waste heat }}}{1-W_{\text {roof }}} \\
H_{\text {waste heat,sunwall }} & =H_{\text {waste heat,shdwall }}=H_{\text {waste heat,roof }}=0 \\
H_{\text {aircond,prvrd }} & =H_{\text {aircond,imprvrd }}=\frac{H_{\text {aircond }}}{1-W_{\text {roof }}} \\
H_{\text {aircond,sunwall }} & =H_{\text {aircond,shdwall }}=H_{\text {aircond,roof }}=0 . \quad \mathrm{A} 2
\end{aligned}
$$

where $W_{\text {roof }}$ is the fraction of roof. The total waste heat from $\mathrm{HAC}$ is

$$
\begin{aligned}
& H_{\text {wasteheat }}=W_{\text {roof }}\left(f_{\text {heat }} F_{\text {heat, roof }}+f_{\text {cool }} F_{\text {cool, roof }}\right)+ \\
& \left(1-W_{\text {roof }}\right) \frac{H}{W}\left(\begin{array}{l}
f_{\text {heat }} F_{\text {heat, sunwall }}+f_{\text {cool }} F_{\text {cool, sunwall }}+ \\
f_{\text {heat }} F_{\text {heat, shdwall }}+f_{\text {cool }} F_{\text {cool, shdwall }}
\end{array}\right) \\
& \leq H_{\text {wasteheat, max }}
\end{aligned}
$$

where $f_{\text {heat }}=1 / 0.75$ and $f_{\text {cool }}=1 / 0.25$ are factors describing the efficiency of HAC systems and $H_{\text {wasteheat,max }}=40 \mathrm{~W} \mathrm{~m}^{-2}$ is a maximum limit on wasteheat at any given time step. The maximum limit is designed to prevent any potential numerical instability at a single time step from causing energy balance problems in the atmospheric model. The heat removed by air conditioning is

$$
H_{\text {aircond }}=F_{\text {cool }} \text {. }
$$


The heating or cooling flux applied to the interior (layer $i=10$ ) of the roof, and sunlit and shaded wall is

$$
\begin{aligned}
F_{\text {heat }} & =\left\{\begin{array}{l|l}
\left|\alpha F_{i=10}^{t}+(1-\alpha) F_{i=10}^{t+1}\right| & T_{\mathrm{BB}}<T_{\min } \\
0 & T_{\mathrm{iB}} \geq T_{\min }
\end{array}\right\} \mathrm{A} 5 \\
F_{\text {cool }} & =\left\{\begin{array}{ll}
\left|\alpha F_{i=10}^{t}+(1+\alpha) F_{i=10}^{t+1}\right| & T_{\mathrm{BB}}>T_{\min } \\
0 & T_{\mathrm{iB}} \leq T_{\min }
\end{array}\right\} \mathrm{A} 6
\end{aligned}
$$

where $\alpha=0.5$ is the averaging coefficient for the Crank-Nicholson method, which combines the explicit method with fluxes evaluated at model time step $t\left(F_{i=10}^{t}\right)$ and the implicit method with fluxes evaluated at time $t+1\left(F_{i=10}^{t+1}\right)$. These fluxes are determined from the coefficients of the tridiagonal system of equations. The internal building temperature, $T_{\mathrm{iB}}$, is constrained to be between the prescribed maximum and minimum internal building temperatures $T_{\mathrm{iB}, \max }$ and $T_{\mathrm{iB} \text {, min }}$.

Nonurban landunits balance energy as

$$
\vec{S}_{\mathrm{u}}-\vec{L}_{\mathrm{u}}-H_{\mathrm{u}}-\lambda E_{\mathrm{u}}-G_{\mathrm{upper}}=0
$$

where, $G_{\text {upper }}$ is the ground or storage heat flux at the upper boundary of the soil/snow column. The storage heat flux is positive into the soil/snow surface. The urban landunit energy balance is

$$
\begin{aligned}
& \vec{S}_{u}-\vec{L}_{u}-H_{u}-\lambda E_{\mathrm{u}}-G_{\text {upper }}+G_{\text {lower }}+H_{\text {waste heat }} \\
& \quad+H_{\text {aircond }}=0
\end{aligned}
$$

where $G_{\text {lower }}$ is the lower boundary condition on roofs and walls, referred to as building heat in the main text, and includes HAC fluxes when the building interior minimum and maximum temperature thresholds are reached. The sign convention for $G_{\text {lower }}$ is defined as positive for energy into the roof/walls (e.g. heating) and negative for energy out of the roof/walls (e.g. cooling). As heat removed by air conditioning is put back into the urban canyon, the air conditioning flux must be added to the energy balance equation. From the perspective of the rest of the climate system then, the energy source or sink due to urban areas is $G_{\text {lower }}+H_{\text {wasteheat }}+$ $H_{\text {aircond. }}$

\section{Acknowledgements}

This research was supported by the National Center for Atmospheric Research Water System Program and the Weather and Climate Impact Assessment Program, National Science Foundation grants ATM-0107404 and ATM-0413540 and the University of Kansas, Center for Research. The National Center for Atmospheric Research is sponsored by the National Science Foundation.

\section{References}

Best MJ. 2006. Progress towards better weather forecasts for city dwellers: from short range to climate change. Theoretical and Applied Climatology 84: 47-55, DOI: 10.1007/s00704-005-0143-2.
Betts RA, Best MJ. 2004. Relative impacts of radiative forcing, landscape effects and local heat sources on simulated climate change in urban areas. BETWIXT Technical Note Briefing Note 6. Available at http://www.cru.uea.ac.uk/projects/betwixt/.

Changnon SA, Kunkel KE, Reinke BC. 1996. Impacts and responses to the 1995 heat wave: A call to action. Bulletin of the American Meteorological Society 77: 1497-1506.

Clark RT, Brown SJ, Murphy JM. 2006. Modelling northern hemisphere summer heat extreme changes and their uncertainties using a physics ensemble of climate sensitivity experiments. Journal of Climate 19: 4418-4435.

Collins WD, Bitz CM, Blackmon ML, Bonan GB, Bretherton CS, Carton JA, Chang P, Doney SC, Hack JJ, Henderson TB, Kiehl JT, Large WG, McKenna DS, Santer BD, Smith RD. 2006a. The Community Climate System Model version 3 (CCSM3). Journal of Climate 19: 2122-2143.

Collins WD, Rasch PJ, Boville BA, Hack JJ, McCaa JR, Williamson DL, Briegleb BP. 2006b. The formulation and atmospheric simulation of the Community Atmosphere Model Version 3 (CAM3). Journal of Climate 19: 2144-2161.

Dobson JE, Bright EA, Coleman PR, Durfee RC, Worley BA. 2000. LandScan: A global population database for estimating populations at risk. Photogrammetric Engineering and Remote Sensing 66: 849-857.

Energy Information Administration (EIA). 2008. 2003 Commercial Buildings Energy Consumption Survey, Energy End-Use Consumption Table E1A. Available at http://www.eia.doe.gov/emeu/ consumption/index.html. [accessed July 2009].

Energy Information Administration (EIA). 2009. 2005 Residential Energy Consumption Survey, Energy Consumption and Expenditures Table US11. Available at http://www.eia.doe.gov/emeu/ consumption/index.html. [accessed July 2009].

Flanner MG. 2009. Integrating anthropogenic heat flux with global climate models. Geophysical Research Letters 36: L02801, DOI:10.1029/2008GL036465.

Gosling SN, Lowe JA, McGregor GR, Pelling M, Malamud BD. 2009a. Associations between elevated atmospheric temperature and human mortality: a critical review of the literature. Climatic Change 92: 299-341, DOI:10.1007/s10584-008-9441-x.

Gosling SN, McGregor GR, Lowe JA. 2009b. Climate change and heat-related mortality in six cities Part 2: climate model evaluation and projected impacts from changes in the mean and variability of temperature with climate change. International Journal of Biometeorology 53: 31-51, DOI:10.1007/s00484-008-0189-9.

Hadley SW, Erickson III DJ, Hernandez JL, Broniak CT, Blasing TJ. 2006. Responses of energy use to climate change: A climate modeling study. Geophysical Research Letters 33: L17703, DOI:10.1029/2006GL026652.

Haeger-Eugensson M, Holmer B. 1999. Advection caused by the urban heat island circulation as a regulating factor on the nocturnal urban heat island. International Journal of Climatology 19: 975-988.

Hawkins TW, Brazel AJ, Stefanov WL, Bigler W, Saffell EM. 2004. The role of rural variability in urban heat island determination for Phoenix, Arizona. Journal of Applied Meteorology 43: 476-486.

Hidalgo J, Masson V, Pigeon G. 2008. Urban-breeze circulation during the CAPITOUL experiment: numerical simulations. Meteorology and Atmospheric Physics 102: 243-262, DOI:10.1007/s00703-0080345-0.

Ichinose T, Shimodozono K, Hanaki K. 1999. Impact of anthropogenic heat on urban climate in Tokyo. Atmospheric Environment 33: 3897-3909.

IPCC. 2007. Climate Change 2007. In The Physical Science Basis. Contribution of Working Group I to the Fourth Assessment Report of the Intergovernmental Panel on Climate Change, Solomon S, Qin D, Manning M, Chen Z, Marquis M, Averyt KB, Tignor M, Miller HL (eds). Cambridge University Press: Cambridge, United Kingdom and New York, NY, USA; 996 pp.

Jackson TL, Feddema JJ, Oleson KW, Bonan GB, Bauer JT. 2010. Parameterization of urban characteristics for global climate modeling. Annals of the Association of American Geographers (in press).

Landsberg HE. 1981. The Urban Climate. Academic Press: New York, USA; 275 pp.

Meehl GA, Tebaldi C. 2004. More intense, more frequent, and longer lasting heat waves in the $21^{\text {st }}$ century. Science 305: 994-997.

Meehl GA, Stocker TF, Collins WD, Friedlingstein P, Gaye AT, Gregory JM, Kitoh A, Knutti R, Murphy JM, Noda A, Raper SCB, Watterson IG, Weaver AJ, Zhao Z.-C. 2007. Global Climate 
Projections. In Climate Change 2007: The Physical Science Basis. Contribution of Working Group I to the Fourth Assessment Report of the Intergovernmental Panel on Climate Change, Solomon S, Qin D, Manning M, Chen Z, Marquis M, Averyt KB, Tignor M, Miller HL (eds). Cambridge University Press: Cambridge, United Kingdom and New York, NY, USA; pp 747-845.

Neale RB, Richter JH, Jochum M. 2008. The impact of convection on ENSO: From a delayed oscillator to a series of events. Journal of Climate 21: 5904-5924, DOI:10.1175/2008JCLI2244.1.

Oke TR, East C. 1971. The urban boundary layer in Montreal. Boundary-Layer Meteorology 1: 411-437.

Oke TR. 1981. Canyon geometry and the nocturnal urban heat island: comparison of scale model and field observations. Journal of Climatology 1: 237-254.

Oke TR. 1987. Boundary Layer Climates. 2nd edn. Routledge: New York, USA.

Oleson KW, Dai Y, Bonan G, Bosilovich M, Dickinson R, Dirmeyer P, Hoffman F, Houser P, Levis S, Niu G-Y, Thornton P, Vertenstein M, Yang Z-L, Zeng X. 2004. Technical description of the Community Land Model (CLM). NCAR Technical Note NCAR/TN-461+STR, $173 \mathrm{pp}$.

Oleson, KW, Bonan GB, Feddema J, Vertenstein M, Grimmond CSB. 2008a. An urban parameterization for a global climate model. 1. Formulation and evaluation for two cities. Journal of Applied Meteorology and Climatology 47: 1038-1060, DOI:10.1175/2007JAMC1597.1.

Oleson KW, Bonan GB, Feddema J, Vertenstein M. 2008b. An urban parameterization for a global climate model. 2. Sensitivity to input parameters and the simulated urban heat island in offline simulations.
Journal of Applied Meteorology and Climatology 47: 1061-1076, DOI:10.1175/2007JAMC1598.1.

Oleson KW, Niu G-Y, Yang Z-L, Lawrence DM, Thornton PE, Lawrence PJ, Stockli R, Dickinson RE, Bonan GB, Levis S, Dai A, Qian T. 2008c. Improvements to the Community Land Model and their impact on the hydrological cycle. Journal of Geophysical Research 113: G01021, DOI:10.1029/2007JG000563.

Qian T, Dai A, Trenberth KE, Oleson KW. 2006. Simulation of global land surface conditions from 1948 to 2004: Part I: Forcing data and evaluations. Journal of Hydrometeorology 7: 953-975.

Stöckli R, Lawrence DM, Niu G-Y, Oleson KW, Thornton PE, Yang ZL, Bonan GB, Denning AS, Running SW. 2008. Use of FLUXNET in the Community Land Model development. Journal of Geophysical Research 113: G01025, DOI:10.1029/2007JG000562.

Trenberth, KE, Jones PD, Ambenje P, Bojariu R, Easterling D, Klein Tank A, Parker D, Rahimzaheh F, Renwick JA, Rusticucci M, Soden B, Zhai P. 2007. Observations: Surface and Atmospheric Climate Change. In Climate Change 2007: The Physical Science Basis. Contribution of Working Group I to the Fourth Assessment Report of the Intergovernmental Panel on Climate Change, Solomon $\mathrm{S}$, Qin D, Manning M, Chen Z, Marquis M, Averyt KB, Tignor M, Miller HL (eds). Cambridge University Press: Cambridge, United Kingdom and New York, NY, USA; 235-336.

Upmanis H, Eliasson I, Lindqvist S. 1998. The influence of green areas on nocturnal temperatures in a high latitude city (Göteborg, Sweden). International Journal of Climatology 18: 681-700.

Zhang, D-L, Shou Y-X, Dickerson R. 2009. Upstream urbanization exacerbates urban heat island effects. Geophysical Research Letters 36: L24401, DOI:10.1029/2009GL041082. 